\title{
30. MINERALOGY AND GEOCHEMISTRY OF UPPER CRETACEOUS AND CENOZOIC SEDIMENTS FROM NORTH BISCAY BAY AND ROCKALL PLATEAU (EASTERN NORTH ATLANTIC), DSDP LEG 48
}

\author{
Pierre Debrabant, ${ }^{1}$ Hervé Chamley, ${ }^{1}$ Janine Foulon, ${ }^{1}$ and Henri Maillot ${ }^{1}$
}

\begin{abstract}
One hundred and thirty samples of various Cretaceous to Pleistocene sediments from DSDP Sites 399 and 400 (north Biscay Bay) and 403 to 406 (south Rockall Plateau) were studied for their clay mineralogy and bulk geochemistry. Both geographical areas were compared with each other, then compared with the area south of Biscay Bay (Site 398, DSDP Leg 47).

In Aptian to Paleogene sediments the clay fraction is dominated by smectite. In Biscay Bay the mineral is rich in $\mathrm{Al}-\mathrm{Fe}$ and chiefly expresses the erosion of soils formed under arid-warm climatic conditions with contrasted wet and dry seasons. Two stages with fibrous clays occur in Albian (attapulgite, palygorskite) and Paleocene/Eocene (attapulgite, sepiolite) sediments, suggesting the existence of wet and warm periods and of nearly closed marginal basins. In the south part of the Iceland Sea the smectite is of a Fe-Mg type and mainly results from the transformation of volcanic material, probably in subaerial conditions. In post-Paleogene sediments the primary minerals (illite, chlorite, quartz, feldspars) and mixed-layers increase irregularly, expressing both periodic continental cooling, the major stages of which occurred in late Miocene and Pleistocene times, an increase in the intensity of the north/south oceanic current. In general, kaolinite and fibrous clays are less abundant, smectite more abundant, and coolings appear to have been stronger in Pleistocene time in the more northern drill sites.

The diagenetic changes are unusual. There is no modification with depth of burial and no basic chemical sedimentation. An in situ evolution in volcanic environment appears locally in Rockall sites only. The "black shales" facies does not induce any argillaceous modification in north Biscay Bay and affects only some chemical elements such as $\mathrm{Ca}, \mathrm{Fe}$, and $\mathrm{Mn}$. Ionic removing and trapping can locally induce the autochthonous crystallization of cristobalite-tridymite and of some zeolites.

Site 402 of Biscay Bay, not as deep as Sites 398, 399, 400, and 401, seems to be aside from open sea circulations, which might affect especially the distribution of Mn in Albian to lower Miocene sediments and, perhaps, as well, that of fibrous clays. The chemical and mineralogical sequence observed from Site 402 to Sites 399 and 400 in Upper Cretaceous sediments suggests a deltaic paleoenvironment, which, seaward is marked by a geochemical homogenization, a decrease of the carbonaceous phase, and an increase of small-sized, highly buoyant minerals (smectite, fibrous clays). The sudden arrival of detrital primary minerals in the Campanian/Maestrichtian suggests the establishment of a deep-sea circulation perhaps related to the opening of the western North Atlantic, or to a tectonic event or a marine regression. South of Rockall Plateau during early Cenozoic time, the chemical and mineralogical environment was more pelagic than in Biscay Bay, especially at Sites 405 and 406 where the volcaniclastic influence was not as strong as at Sites 403 and 404 . The ending of the major volcanic activity in mid-Eocene was followed by an increase in the pelagic supply, probably related to the widening of the eastern North Atlantic.
\end{abstract}

\section{INTRODUCTION}

Leg 48 of the Deep Sea Drilling Project was located in the eastern North Atlantic Ocean, partly in Biscay Bay and 
partly on the Rockall Plateau. Four holes were drilled in each area, Sites 399 to 402 and Sites 403 to 406 , respectively (Figure 1); their general character is as follows (for detailed description see Site Chapters, this volume).

\section{Bay of Biscay}

Site $399\left(47^{\circ} 23.4^{\prime} \mathrm{N}, 09^{\circ} 13.3^{\prime} \mathrm{W} ; 4399 \mathrm{~m}\right.$ water depth; $72.5 \mathrm{~m}$ sub-bottom depth); located at the foot of the Meriadzek Terrace Escarpment; Pleistocene section.

Site $400\left(47^{\circ} 22.90^{\prime} \mathrm{N}, 09^{\circ} 11.90^{\prime} \mathrm{W} ; 4399 \mathrm{~m}\right.$ water depth; $768.5 \mathrm{~m}$ sub-bottom depth); located near to Site 399 at the foot of the Meriadzek Terrace Escarpment; section from Pleistocene to lowermost Aptian.

Site $401\left(47^{\circ} 25.65^{\prime} \mathrm{N}, 08^{\circ} 48.62^{\prime} \mathrm{W} ; 2495 \mathrm{~m}\right.$ water depth; $341 \mathrm{~m}$ sub-bottom depth); located at the edge of the Meriadzek Terrace on an elevated fault block; section from Pleistocene to Kimmeridgian, with major hiatuses between Upper Jurassic and Upper Cretaceous, and between Eocene and Pleistocene.

Site $402\left(47^{\circ} 52.48^{\prime} \mathrm{N}, 08^{\circ} 50.44^{\prime} \mathrm{W} ; 2339.5 \mathrm{~m}\right.$ water depth; $469.5 \mathrm{~m}$ sub-bottom depth); located in a canyon cutting a spur on the Armorican slope; section from Pleistocene to Aptian with a major hiatus between Albian and middle Eocene.

\section{Rockall Plateau}

Four sites were drilled in two sectors: Sites 403 and 404 lie in the southwest margin of the plateau in 2317 to 2322

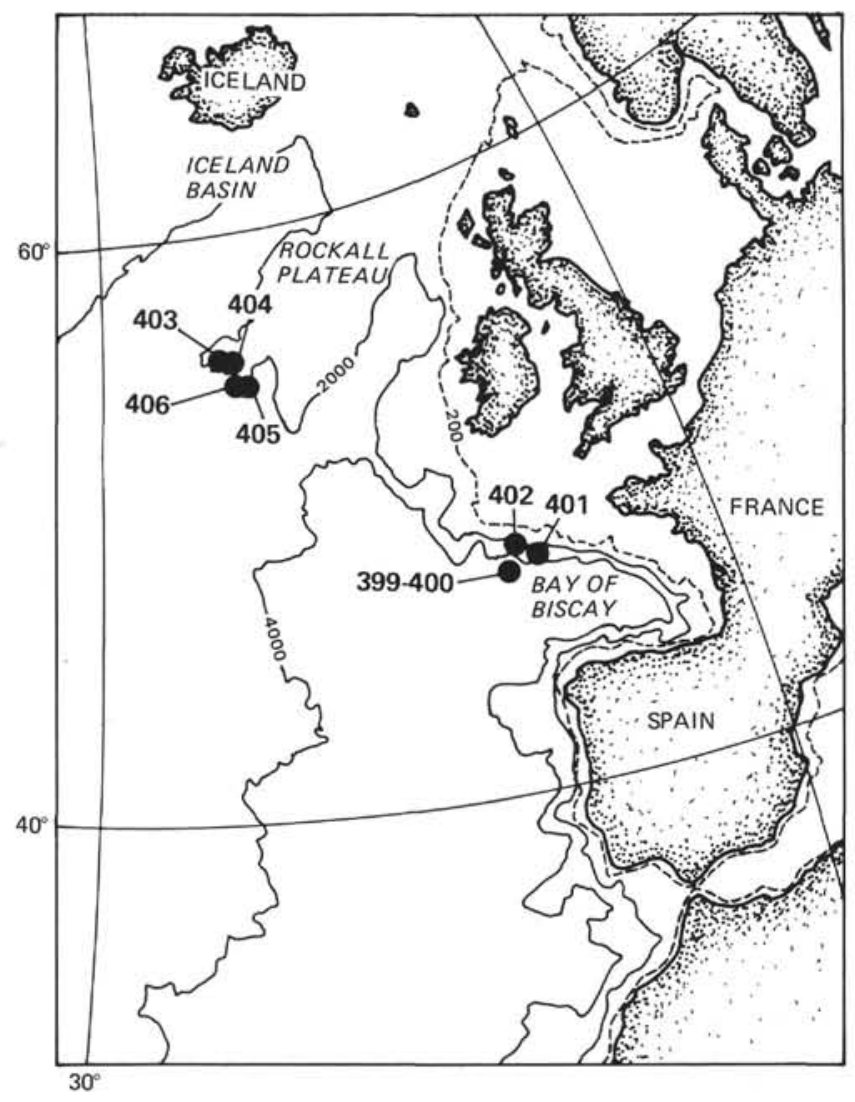

Figure 1. Location map. meters water depths, at $56^{\circ} 08.13^{\prime} \mathrm{N}-23^{\circ} 17.64^{\prime} \mathrm{W}$ and $56^{\circ} 03.13^{\prime} \mathrm{N}-23^{\circ} 14.95^{\prime} \mathrm{W}$, respectively. The sub-bottom depths of the holes were 489 meters and 389 meters, respectively, the oldest sediment cored being upper Paleocene in both cases. A major gap exists from middle Eocene to upper Miocene, except at Site 403 where a thin interval of Oligocene sediments is present.

Sites 405 and 406 lie south of the east-west scarp forming part of the southwest margin of the plateau in 2958 meter and 2907 meter water depths at $55^{\circ} 20.18^{\prime} \mathrm{N}-22^{\circ} 03.49^{\prime} \mathrm{W}$ and $55^{\circ} 15.50^{\prime} \mathrm{N}-22^{\circ} 05.41^{\prime} \mathrm{W}$, respectively. Sub-bottom depths are 407 meters and 831.5 meters, respectively, the bottom sediments at each site being of early Eocene age. Site 405 shows a major hiatus between lower Eocene and upper Miocene. At Site 406 only middle Eocene and lower Oligocene are missing.

About 130 samples from the eight sites were studied for the purpose of comparing the clay mineralogy, bulk mineralogy (locally), and the bulk geochemistry. Results are presented on Figures 2 to 8 and will be commented briefly upon in stratigraphical order. Comparison first is made among all sites of each area, then between Biscay Bay, Rockall Plateau, and the Vigo Seamounts south of Biscay Bay (DSDP Leg 47B, Chamley et al., in press). Note that complementary data and comments on mineralogy are given about Biscay Bay by Cassat (this volume) and about Rockall Plateau by Latouche (this volume).

\section{METHODS OF INVESTIGATION}

\section{Clay Mineralogy}

All of the samples were submitted to X-ray diffraction analysis on $<2 \mu \mathrm{m}$ decalcified particles. We examined some of $<8 \mu \mathrm{m}$ non-calcareous fractions by transmission electromicroscopy. Differential thermal analyses were made on $<2 \mu \mathrm{m}$ non-calcareous fractions of selected samples originating chiefly from sites of Rockall Plateau. In the $\mathrm{X}$-ray diffraction method, the samples were dissociated in water then decarbonized in $N 5$ hydrochloric acid; the excess acid was removed by successive centrifugations. A microhomogenization led to deflocculation. The $<2 \mu \mathrm{m}$ fraction was collected by decantation (Stokes law), then oriented aggregates were made on glass slides. A CGR $\theta 60$ diffractometer (copper radiation focused by a quartz curved-crystal monochromator) was used to run the X-ray diffraction scans at $1^{\circ} 2 \Theta / \mathrm{mn}$. A receiving slit of $1.25 \mathrm{~mm}$ allowed a better determination of mixed-layer minerals. Four passages are carried out as follows: (a) from $1^{\circ}$ to $15^{\circ}$ $\theta$ on natural sample; (b) from $1^{\circ}$ to $7^{\circ} \theta$ on glycolated sample; (c) from $1^{\circ}$ to $7^{\circ} \theta$ on sample heated for two hours at $490^{\circ} \mathrm{C}$; (d) from $12^{\circ}$ to $14^{\circ} \Theta$ on hydrazine-hydrated sample.

Semiquantitative evaluations were based on the peak heights and areas (Chamley, 1971). The height of 001 illite and chlorite peaks (diagram of glycolated sample) were taken as references. Compared to these values, smectite, attapulgite, and irregular mixed-layers were corrected in addition to peak heights whereas well crystallized kaolinite was corrected in diminution. The balance between chlorite and kaolinite results from peak heights ratio (respectively $3.54 \AA$ and $3.58 \AA$ ): when this ratio is 1 , the amount of 
chlorite is assumed to be twice as much as that of kaolinite. Final data are given in percentages, the relative error being \pm 5 per cent.

\section{GEOCHEMISTRY}

The samples were dried at $105^{\circ} \mathrm{C}$, then ground and homogenized; $0.2 \mathrm{~g}$ was submitted to alkaline fusion, then solubilized by $\mathrm{HCl}$, and diluted to $100 \mathrm{ml}$. The treatment allows gravimetric determination of $\mathrm{SiO}_{2}$, colorimetric determination of $\mathrm{P}_{2} \mathrm{O}_{5}$, and spectrophotometric determination of $\mathrm{Fe}, \mathrm{CaO}, \mathrm{MgO}, \mathrm{Al}_{2} \mathrm{O}_{3}$ (by atomic absorption). Another 2 $\mathrm{g}$ of each sample were submitted to fluoroperchloric treatment, then solubilized by $\mathrm{HCl}$ and diluted to $100 \mathrm{ml}$. The dilution is used for the colorimetric analysis of $\mathrm{TiO}_{2}$, the spectrophotometric analysis of $\mathrm{Na}_{2} \mathrm{O}$ and $\mathrm{K}_{2} \mathrm{O}$ (by emission) and also for traces $\mathrm{Mn}, \mathrm{Zn}, \mathrm{Li}, \mathrm{Ni}, \mathrm{Cr}, \mathrm{Sr}, \mathrm{Co}, \mathrm{Cu}$, $\mathrm{Pb}, \mathrm{V}$ (by atomic absorption).

The emission and atomic absorption apparatus was a Type 503 Perkin-Elmer spectrophotometer using the following methods-base solution for major elements or complex synthetic solution for trace elements to which 5 per cent of lanthane in hydrochloric solution is added.

\section{BISCAY BAY-RESULTS}

\section{Sites 399 and 400; Figure 2; Table 1}

\section{Aptian}

Aptian and Albian sediments are carbonaceous mudstone, marly nannofossil chalk, and calcareous claystone (lithologic Unit 4). In some levels smectite is nearly exclusive, accompanied by rather high contents of $\mathrm{Fe}$ and Mn rather than K. Particular levels locally exist which show reduction (400A-74-1, $45 \mathrm{~cm}$ : siderite, rhodochrosite) or oxidation (400A-68-2, $49 \mathrm{~cm}$ ): irregular mixed-layers illite-smectite and chlorite-smectite, goethite, subamorphous iron oxides); both types show an antagonism between $\mathrm{SiO}_{2} / \mathrm{Al}_{2} \mathrm{O}_{3}$ and $\mathrm{Al}_{2} \mathrm{O}_{3} / \mathrm{K}_{2} \mathrm{O}$ ratios.

\section{Albian}

Smectite is the main clay mineral, as it is in all sediments up to those of the Miocene at least. Associate minerals are chlorite, illite, kaolinite, attapulgite (Plate 1; Figures 1, 2), quartz, feldspars, zeolites (clinoptilolite). $\mathrm{Mn}$ and $\mathrm{Ca}$ increase whereas the $\mathrm{Sr} / \mathrm{CaO}$ ratio is variable.

\section{Campanian/Maestrichtian}

Four levels $(-61-3,136 \mathrm{~cm},-61-1,26 \mathrm{~cm},-60-3,11 \mathrm{~cm}$, $-60-1,4 \mathrm{~cm}$ ) studied for clay mineralogy in the nannofossil chalk of Unit 3 show the presence, besides smectite, of 10 to 35 per cent illite, and a large amount of quartz and feldspars. Chlorite is more abundant than below and above; amphiboles are locally present in the $<2 \mu \mathrm{m}$ fraction.

\section{Upper Paleocene, Eocene}

Siliceous mudstone, calcareous claystone, and marly chalk from the base of lithologic Unit 2 contain a large amount of smectite. Kaolinite increases upwards as well as the $\mathrm{Al}_{2} \mathrm{O}_{3} / \mathrm{K}_{2} \mathrm{O}$ ratio, whereas $\mathrm{CaO}$ decreases. Attapulgite and/or sepiolite are present, especially in middle Eocene sediments. Zeolites occur rarely, then disappear in the middle Eocene interval. $\mathrm{MgO} / \mathrm{K}_{2} \mathrm{O}$ and $\mathrm{Sr} / \mathrm{CaO}$ ratios increase, with a maximum at the Eocene/Oligocene boundary.

\section{Oligocene, Lower Miocene}

The siliceous marly nannofossil chalk and mudstone of the upper part of Unit 2 show several trends upwards from the Eocene/Oligocene boundary: stabilization of $\mathrm{Sr} / \mathrm{CaO}$ ratio; increase of $\mathrm{Ca}, \mathrm{Mn}$, illite, and kaolinite; appearance, then development of chlorite; disappearance of fibrous clays on X-ray diagrams, fibers subsisting on electromicrographs in small quantities only (Plate 1; Figure 5); in middle Miocene, end of metallization.

\section{Upper Miocene to Pleistocene}

Lithologic Unit 1, nannofossil and marly nannofossil ooze, and calcareous mud, is marked by an irregular decrease of smectite and increase in the abundance of illite, chlorite, followed in turn by irregular mixed-layers, quartz, feldspars, amphiboles, and goethite. Attapulgite appears in small quantities on micrographs. At the base of the zone is a geochemical break manifested by increase of $\mathrm{Ca}$ and $\mathrm{Sr}$, and decrease of $\mathrm{Mn}, \mathrm{SiO}_{2} / \mathrm{Al}_{2} \mathrm{O}_{3}$ and $\mathrm{Al}_{2} \mathrm{O}_{3} / \mathrm{K}_{2} \mathrm{O}$. The Pleistocene is marked by an increase in $\mathrm{SiO}_{2}, \mathrm{Ti}, \mathrm{Cr}, \mathrm{V}$, and $\mathrm{Zn}$ contents.

\section{Site 401; Figure 3; Table 2}

\section{Kimmeridgian}

The Upper Jurassic limestone (Unit 4) is poor in clay fraction; it could not be extracted in sufficient amounts for $\mathrm{X}$-ray analysis. The richness of $\mathrm{Ca}$ is followed by high $\mathrm{MgO} / \mathrm{K}_{2} \mathrm{O}$ ratios, low $\mathrm{Sr} / \mathrm{CaO}$ ratios.

\section{Campanian}

Illite and chlorite constitute more than half of the clay fraction $(19-1,125 \mathrm{~cm})$ and are marked by relative high contents of $\mathrm{Al}$ and $\mathrm{K}$. $\mathrm{CaCO}_{3}$ is abundant; $\mathrm{Sr} / \mathrm{CaO}$ ratio continues to be low. Phosphates are locally individualized. A resampling and study of Cores 18 and 19 (Campanian and Maestrichtian: $-18-1,50 \mathrm{~cm},-18-2,49 \mathrm{~cm},-18-2,88 \mathrm{~cm}$, $-19-1,8 \mathrm{~cm},-19-1,50 \mathrm{~cm},-19-1,90 \mathrm{~cm}$ ) lead to the following average clay mineralogy: chlorite 5 per cent, illite 35 per cent, irregular mixed-layers illite-smectite and chlorite-smectite 5 per cent, smectite 45 per cent, kaolinite 5 per cent, attapulgite 5 per cent, sepiolite traces; associate minerals are abundant quartz, feldspars and, locally, amphiboles. Illite and chlorite particles are often large sized and well edged (Plate 1; Figure 3).

\section{Paleocene, Eocene}

The nannofossil, marly or calcareous chalks of lithologic Units 3 and 2 are marked by abundant smectite, with locally rather abundant attapulgite, sepiolite, and clinoptilolite (resample of $-17-1,50 \mathrm{~cm}$, Plate 1, Figure 4). Illite, chlorite, $\mathrm{SiO}_{2} / \mathrm{Al}_{2} \mathrm{O}_{3}$, and $\mathrm{Sr} / \mathrm{CaO}$ ratios increase more or less progressively towards upper Eocene. In lower Paleocene a large increase of $\mathrm{Sr}$ and $\mathrm{Mn}$ occurs, the latter element showing a maximum in middle Eocene where sepiolite content is the larger. 
MINERALOGICAL AND GEOCHEMICAL BULK

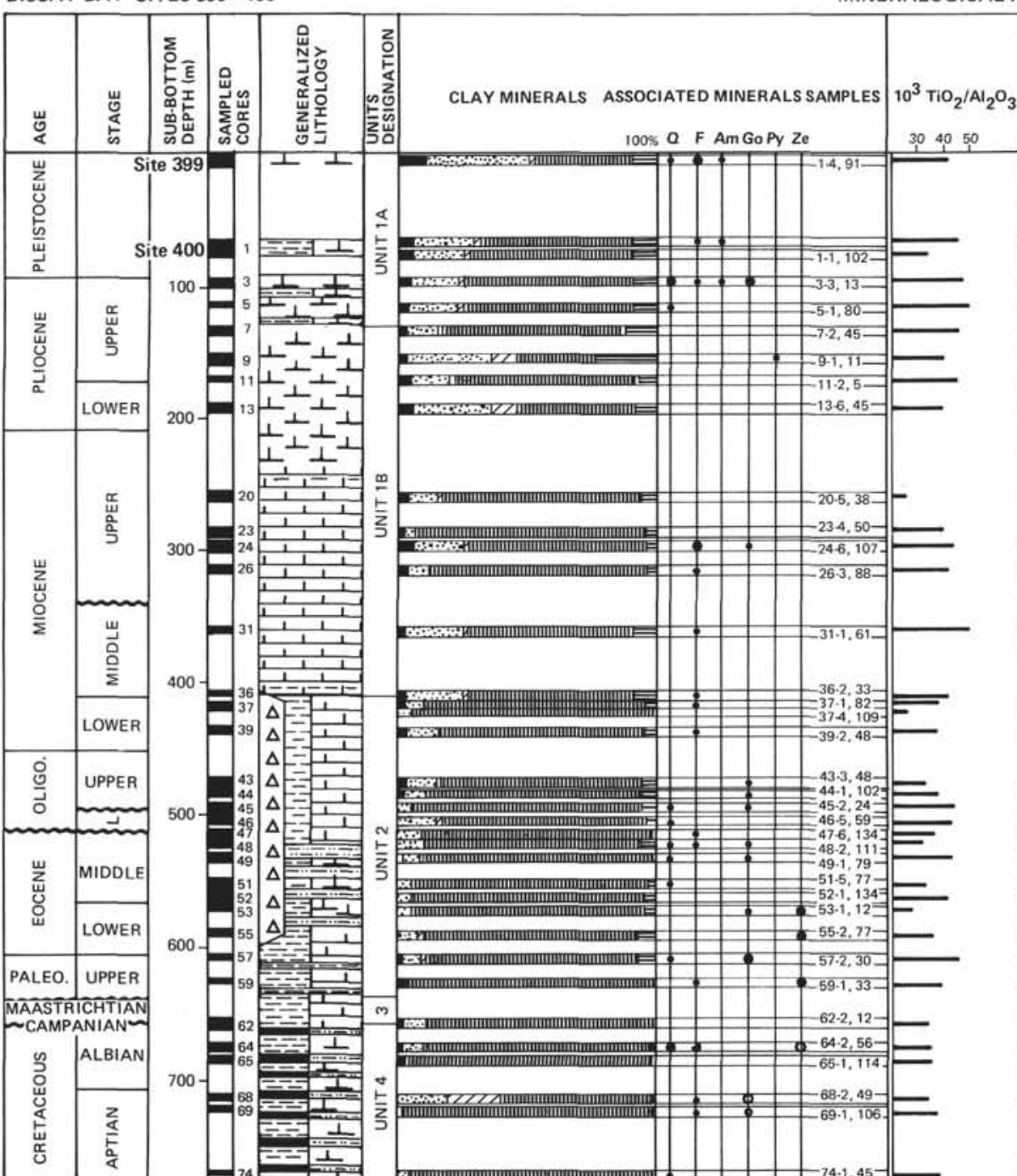

CLAY MINERALS:

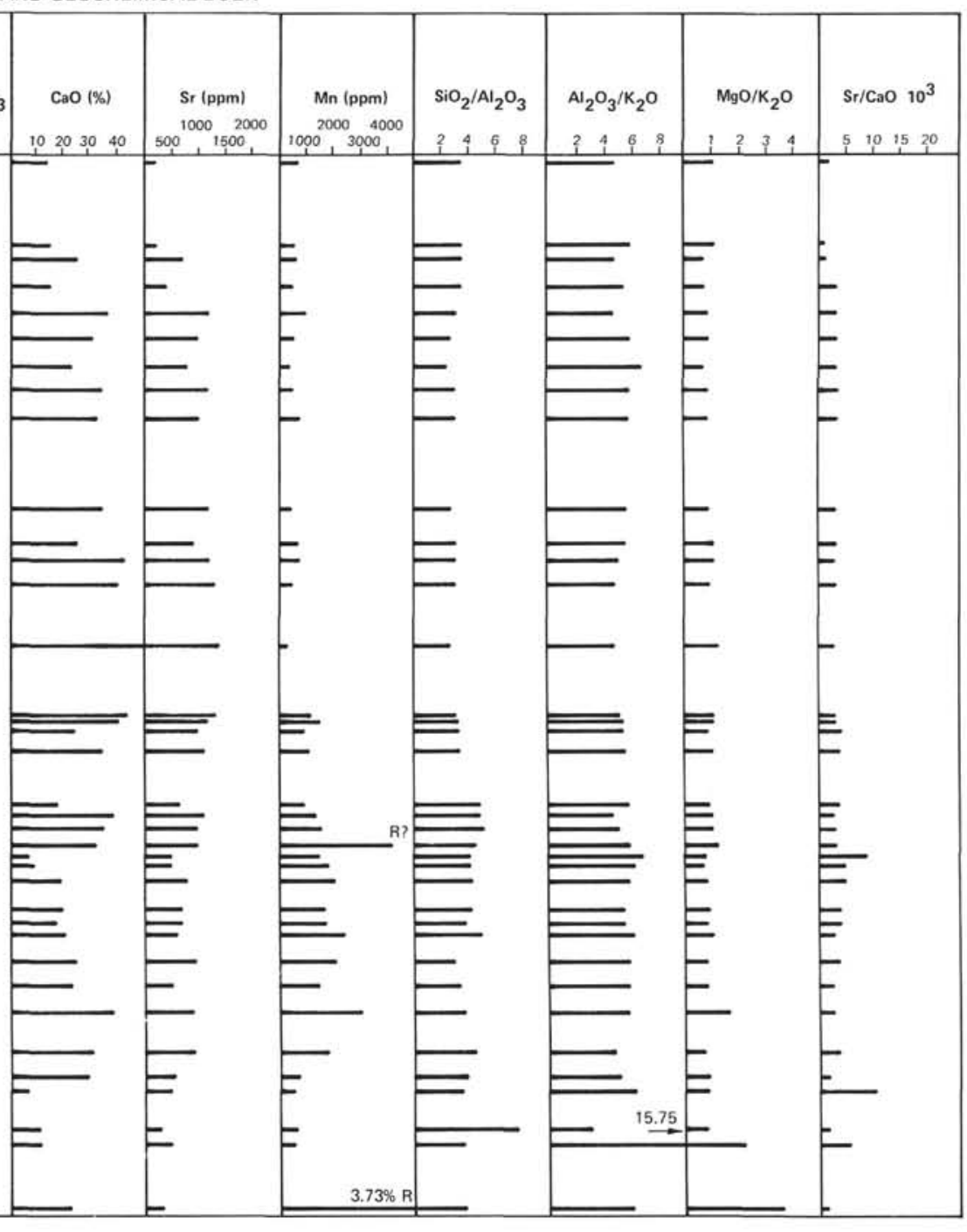

ASSOCIATED MINERALS:

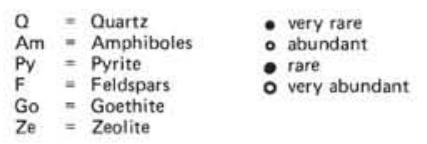

Figure 2. Sites 399 and 400, clay mineralogy and bulk geochemistry.

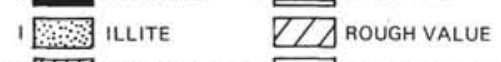

$$
\begin{aligned}
& \text { ML UIA MIXED LAYERS } \square \text { ATTAPULGITE (Low or very low clay content) }
\end{aligned}
$$

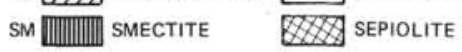


TABLE 1

Geochemical Data, Sites 339 and 400

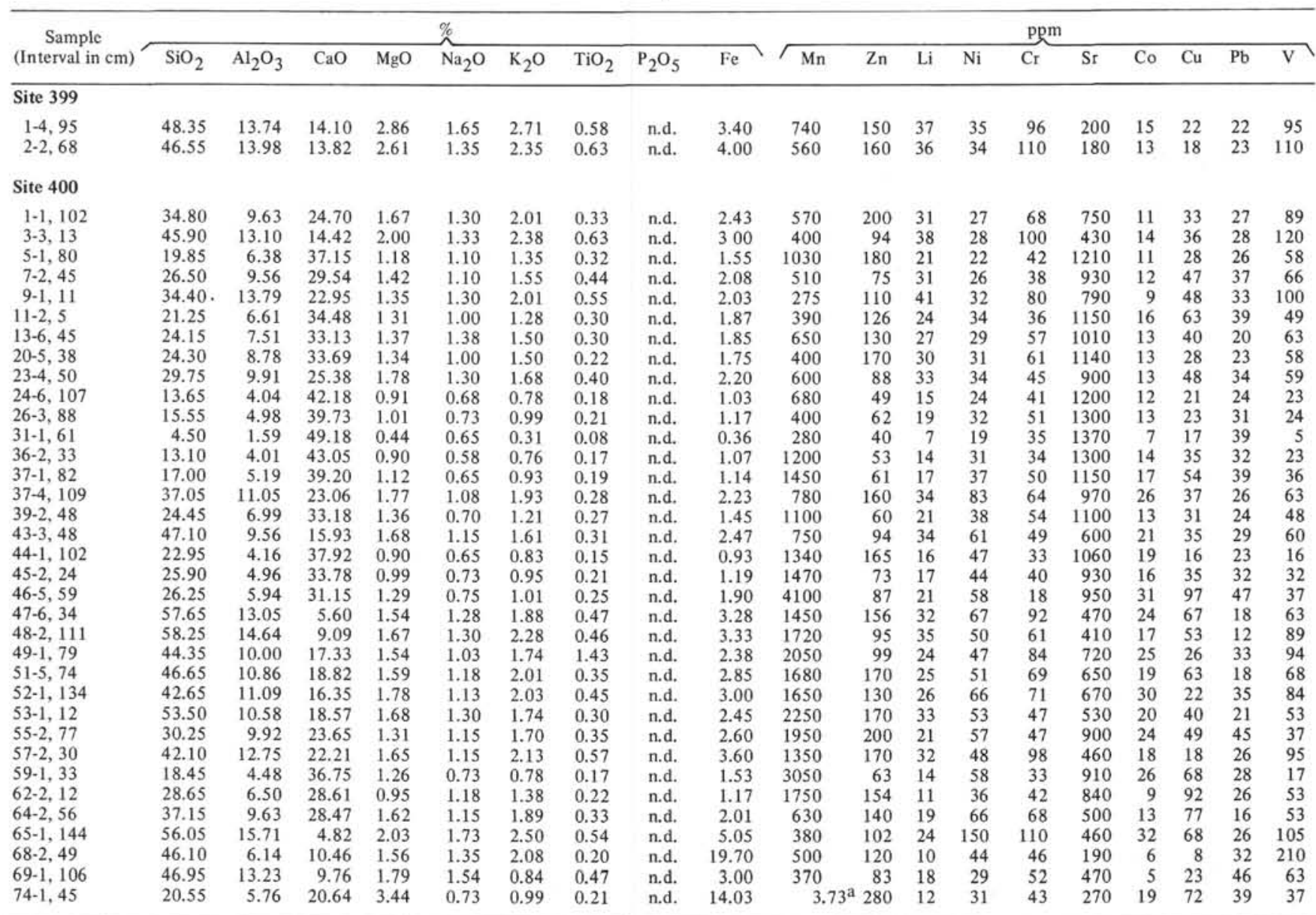

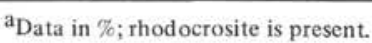

\section{Pleistocene}

The marly calcareous ooze of Unit 1 contains illite, chlorite, irregular mixed-layers, relatively abundant associate primary minerals, accompanied by high values of $\mathrm{SiO}_{2}, \mathrm{~K}_{2} \mathrm{O}, \mathrm{Ti}, \mathrm{Cr}$, and low contents of $\mathrm{Sr}$ and $\mathrm{Mn}$.

\section{Site 402; Figure 4; Table 2}

\section{Aptian, Albian}

In the carbonaceous sediments of lithologic Units 3 and 2 , smectite is abundant and well crystallized, followed by illite and kaolinite. Clinoptilolite occurs in Albian only, as at Site 400 . The silty samples show an increase of illite and kaolinite content. $\mathrm{Ca}$ is high and variable. Pyrite is present especially in the lower Albian "black shales," Geochemical changes occur in upper Albian, where smectite is very abundant, manifested by stabilization of $\mathrm{Al}_{2} \mathrm{O}_{3} / \mathrm{K}_{2} \mathrm{O}$ ratio, low content of transition elements $(\mathrm{Mn}, \mathrm{Co}, \mathrm{Cu})$, and local augmentation of $\mathrm{SiO}_{2} / \mathrm{Al}_{2} \mathrm{O}_{3}$ ratios.

\section{Cenomanian}

At level 9A-1, $40 \mathrm{~cm}$, where the Albian/Cenomanian transition is located, clay minerals are rare; silicates (cristobalite) are abundant, accompanied by relative high values of $\mathrm{Co}$ and $\mathrm{MgO} / \mathrm{K}_{2} \mathrm{O}$. Minimal values occur in $\mathrm{Fe}$, $\mathrm{Ni}, \mathrm{Cu}, \mathrm{Pb}$ and $\mathrm{V}$ contents.

\section{Middle Eocene}

In the nannofossil chalk to siliceous marly nannofossil chalk of Sub-unit 1B, an increase of illite occurs upwards, whereas chlorite, irregular mixed-layers, kaolinite, quartz, and feldspars appear in the clay fraction. $\mathrm{Ca}$ and $\mathrm{Mn}$ increase; $\mathrm{Al}_{2} \mathrm{O}_{3}$ is little present. Zeolites are absent and fibrous clays are absent or rare.

\section{Pliocene, Pleistocene}

The marly calcareous ooze of Sub-unit 1A, as at other sites, shows decreased smectite whereas primary or little weathered minerals such as illite, chlorite, mixed-layers, quartz, and feldspars increase.

\section{DISCUSSION}

\section{General Mineralogical and Geochemical Evolution}

No progressive and continuous change is observed along the mineral and chemical assemblages of the sediments 


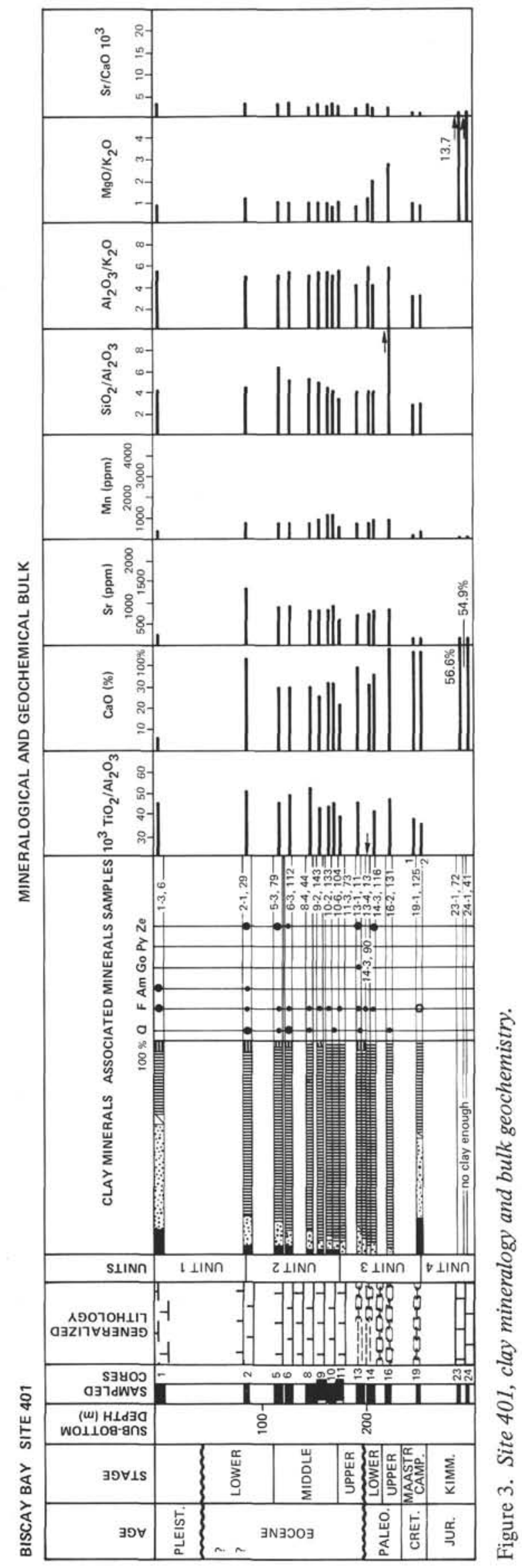

from Upper Jurassic to Pleistocene recovered from Sites $399,400,401$ and 402 . This demonstrates the absence of diagenetic evolution associated with depth of burial and confirms the results obtained from other sites in the North Atlantic margins (von Rad and Rösch, 1972; Chamley and Giroud d'Argoud, in press; Chamley et al., in press; Pastouret et al., 1978, etc.).

From Cretaceous to upper Eocene the sediments are marked by an abundant smectite mineral phase associated with $\mathrm{Al}, \mathrm{Fe}, \mathrm{Ti}, \mathrm{V}, \mathrm{Ca}, \mathrm{Li}$. That phase is virtually independent of lithology, and is not related to volcanic materials or chemical sediments. An essentially detrital origin must be envisaged, which must have been derived either from ancient continental rocks subjected to erosion or newly formed continental soils. Both sources could have provided the sediment, but soils would most likely have been the principal one on account of the vulnerability of superficial formations and of the broad development of soils in Cretaceous depressed landscapes.

Such a mainly pedological origin of the smectites deposited in Biscay Bay suggests that the continental climate was warm and arid with alternating dry and wet seasons (Paquet, 1969). The detrital origin of smectite is supported by the data of accompanying rare earth elements of typical continental assemblage (analysis of C. Courtois, Paris).

From upper Eocene to Pleistocene the sediments show irregular but continuous increase in primary clayey minerals (illite, chlorite associated with $\mathrm{Al}_{2} \mathrm{O}_{3}$ and $\mathrm{K}_{2} \mathrm{O}$ ), together with irregular mixed-layers of low degradation and non-argillaceous detrital minerals (quartz, feldspars, and, in places, amphiboles). This change, which is particularly marked from upper Miocene into Pleistocene, suggests a general trend to climatic cooling which disfavors soil development and favors direct erosion of rocks. This conclusion agrees with the isotopic data of calcareous organisms for the Leg 48 sites (Létolle and VergnaudGrazzini, this volume). Another cause may have been the effect of Atlantic widening accompanied by development of meridian currents and the rejuvenation of European reliefs in the Paleogene with consequent increased continental erosion.

Marked geochemical changes occur at various boundaries such as between Aptian/Albian (Site 402), and Albian/ Paleocene, Eocene/Oligocene, and lower-middle Miocene (Site 400). The changes vary in nature, but are not accompanied by dolomitization or phosphatization. In the hypothesis of a warm and wet climate, proposed on mineralogical grounds, margin tectonism should provoke organic or inorganic precipitation of phosphate in association with upwelling currents on the outer edge of continental shelf (Krauskopft, 1967). Phosphate being absent, the geochemical changes may be due to a climatic or current control.

Fibrous clay stages occur in the Albian (attapulgite $=$ palygorskite) as well as at Paleocene/Eocene boundary (attapulgite, sepiolite) in the two deeper Sites, 400 and 401. Those minerals with short broken fibers, widely spread among detrital minerals in various reworked sediments, have a detrital origin. Their development is favored by a particularly warm, wet climate favoring ionic mobilization 
TABLE 2

Geochemical Data, Sites 401 and 402

\begin{tabular}{|c|c|c|c|c|c|c|c|c|c|c|c|c|c|c|c|c|c|c|c|}
\hline \multirow{2}{*}{$\begin{array}{c}\text { Sample } \\
\text { (Interval in } \mathrm{cm} \text { ) }\end{array}$} & \multicolumn{9}{|c|}{$\%$} & \multicolumn{10}{|c|}{ ppm } \\
\hline & $\mathrm{SiO}_{2}$ & $\mathrm{Al}_{2} \mathrm{O}_{3}$ & $\mathrm{CaO}$ & $\mathrm{MgO}$ & $\mathrm{Na}_{2} \mathrm{O}$ & $\mathrm{K}_{2} \mathrm{O}$ & $\mathrm{TiO}_{2}$ & $\mathrm{P}_{2} \mathrm{O}_{5}$ & $\mathrm{Fe}$ & Mn & $\mathrm{Zn}$ & $\mathrm{Li}$ & $\mathrm{Ni}$ & $\mathrm{Cr}$ & $\mathrm{Sr}$ & $\mathrm{Co}$ & $\mathrm{Cr}$ & $\mathrm{Pb}$ & V \\
\hline \multicolumn{20}{|l|}{ Site 401} \\
\hline $1-3,6$ & 54.00 & 13.17 & 7.31 & 2.03 & 1.60 & 2.36 & 0.59 & n.d. & 3.25 & 440 & 95 & 28 & 27 & 110 & 230 & 11 & 13 & 24 & 68 \\
\hline $2-1,29$ & 13.00 & 3.03 & 43.38 & 0.78 & 0.80 & 0.63 & 0.15 & n.d. & 0.85 & 660 & 120 & 8 & 24 & 27 & 1350 & 10 & 12 & 31 & 63 \\
\hline $5-3,79$ & 28.25 & 4.52 & 30.33 & 0.99 & 0.98 & 0.95 & 0.20 & n.d. & 1.21 & 760 & 210 & 11 & 24 & 41 & 920 & 7 & 24 & 23 & 68 \\
\hline $6-3,112$ & 29.10 & 5.85 & 29.38 & 1.01 & 0.98 & 1.06 & 0.28 & n.d. & 1.49 & 780 & 110 & 11 & 25 & 56 & 900 & 7 & 15 & 15 & 84 \\
\hline $8-4,44$ & 31.80 & 6.02 & 30.45 & 1.14 & 0.90 & 1.25 & 0.31 & n.d. & 1.70 & 670 & 71 & 12 & 32 & 31 & 810 & 14 & 16 & 26 & 42 \\
\hline $9-2,143$ & 32.80 & 6.61 & 26.34 & 1.01 & 1.03 & 1.23 & 0.28 & n.d. & 1.65 & 1050 & 140 & 12 & 38 & 43 & 800 & 16 & 58 & 18 & 95 \\
\hline $10-2,133$ & 24.70 & 5.73 & 31.76 & 0.94 & 0.80 & 1.10 & 0.24 & n.d. & 1.43 & 1100 & 100 & 9 & 53 & 44 & 870 & 52 & 170 & 25 & 115 \\
\hline $10-6,104$ & 25.95 & 6.20 & 31.17 & 1.00 & 0.88 & 1.23 & 0.28 & n.d. & 1.45 & 1200 & 160 & 10 & 33 & 33 & 950 & 13 & 19 & 21 & 100 \\
\hline $11-3,73$ & 34.50 & 10.51 & 22.35 & 1.65 & 1.35 & 1.91 & 0.40 & n.d. & 2.71 & 460 & 225 & 20 & 36 & 56 & 580 & 18 & 26 & 38 & 37 \\
\hline $13-1,71$ & 16.25 & 4.12 & 38.83 & 0.82 & 0.80 & 1.03 & 0.18 & n.d. & 1.21 & 750 & 207 & 8 & 29 & 53 & 710 & 8 & 45 & 29 & 42 \\
\hline $14-3,90$ & 32.30 & 8.44 & 30.92 & 1.65 & 0.94 & 1.48 & 0.05 & n.d. & 2.09 & 720 & 260 & 15 & 34 & 61 & 730 & 13 & 30 & 19 & 95 \\
\hline $14-3,116$ & 20.35 & 5.19 & 36.05 & 2.65 & 0.96 & 1.29 & 0.21 & n.d. & 1.40 & 990 & 127 & 9 & 46 & 32 & 780 & 11 & 34 & 25 & 130 \\
\hline $16-2,131$ & 14.85 & 1.51 & 48.97 & 0.72 & 0.70 & 0.26 & 0.07 & n.d. & 0.48 & 950 & 85 & 6 & 27 & 16 & 840 & 9 & 29 & 28 & 63 \\
\hline $19-1,125.1^{\mathrm{a}}$ & 7.10 & 2.72 & 46.17 & 0.86 & 0.39 & 0.94 & 0.10 & n.d. & 0.63 & 79 & 250 & 8 & 20 & 38 & 140 & 6 & 15 & 33 & 37 \\
\hline $19-1,125.2^{\mathrm{a}}$ & 9.45 & 3.50 & 45.82 & 0.86 & 0.50 & 1.13 & 0.12 & 0.83 & 1.35 & 300 & 140 & 11 & 26 & 31 & 160 & 6 & 28 & 32 & 53 \\
\hline $23-1,72$ & n.d. & n.d. & 54.57 & 0.41 & 0.16 & 0.03 & n.d. & n.d. & n.d. & 16 & 72 & n.d. & 11 & 13 & 150 & 24 & 8 & 33 & n.d. \\
\hline $24-1,41$ & n.d. & n.d. & 54.92 & 0.51 & 0.14 & 0.03 & n.d. & n.d. & n.d. & 16 & 82 & n.d. & 9 & 13 & 160 & 15 & 6 & 32 & n.d. \\
\hline \multicolumn{20}{|l|}{ Site 402} \\
\hline $1-2,12$ & 54.55 & 9.33 & 10.18 & 1.85 & 1.48 & 2.10 & 0.41 & n.d. & 2.40 & 340 & 140 & 23 & 14 & 89 & 350 & 5 & 13 & 79 & 53 \\
\hline$W_{1} \bar{b}$ & 31.15 & 4.49 & 28.58 & 1.27 & 0.94 & 1.05 & 0.25 & n.d. & 1.25 & 140 & 93 & 17 & 12 & 56 & 920 & 2 & 20 & 21 & 53 \\
\hline $\mathrm{W} 2 \mathrm{~b}$ & 13.95 & 2.68 & 41.28 & 0.91 & 0.84 & 0.61 & 0.14 & n.d. & 0.65 & 130 & 87 & 11 & 15 & 48 & 1420 & $?$ & 16 & 28 & 37 \\
\hline $3-1,143$ & 33.75 & 4.43 & 34.71 & 0.89 & 1.20 & 1.04 & 0.25 & n.d. & 1.19 & 150 & 72 & 15 & 13 & 57 & 720 & 4 & 13 & 240 & 47 \\
\hline $5-1,16$ & 23.60 & 4.09 & 38.83 & 1.13 & 1.15 & 0.98 & 0.16 & n.d. & 1.13 & 860 & 76 & 19 & 25 & 54 & 1020 & 8 & 10 & 25 & 58 \\
\hline $1-4,118$ & 32.90 & 5.90 & 32.39 & 1.16 & 0.98 & 1.18 & 0.27 & n.d. & 1.55 & 280 & 120 & 20 & 16 & 33 & 920 & 4 & 12 & 25 & 95 \\
\hline $3-2,129$ & 37.85 & 4.70 & 30.68 & 1.08 & 1.05 & 0.96 & 0.20 & n.d. & 1.31 & 260 & 115 & 15 & 14 & 56 & 680 & 2 & 11 & 16 & 89 \\
\hline $4-2,81$ & 46.50 & 6.09 & 23.19 & 1.19 & 1.20 & 1.28 & 0.23 & n.d. & 1.55 & 360 & 93 & 18 & 11 & 69 & 670 & 6 & 7 & 26 & 16 \\
\hline $4-3,12$ & 45.10 & 7.97 & 23.93 & 1.24 & 1.23 & 1.35 & 0.28 & n.d. & 1.64 & 420 & 130 & 20 & 13 & 68 & 610 & 7 & 7 & 27 & 37 \\
\hline $9-1,38$ & 51.15 & 1.06 & 29.64 & 0.57 & 0.35 & 0.29 & 0.07 & n.d. & 0.27 & 80 & 29 & 5 & 9 & 39 & 670 & 24 & 5 & 7 & 21 \\
\hline $11-3,140$ & 48.45 & 8.86 & 22.26 & 1.25 & 1.24 & 1.43 & 0.33 & n.d. & 1.42 & 90 & 113 & 119 & 15 & 68 & 1340 & 5 & 8 & 31 & 63 \\
\hline $13-2,101$ & 31.10 & 9.09 & 28.32 & 1.73 & 1.25 & 1.40 & 0.36 & n.d. & 2.19 & 170 & 97 & 26 & 31 & 53 & 1370 & 6 & 12 & 31 & 84 \\
\hline $15-5,75$ & 46.25 & 11.10 & 20.50 & 1.17 & 1.04 & 1.68 & 0.46 & n.d. & 1.71 & 69 & 130 & 35 & 31 & 89 & 1220 & 6 & 13 & 32 & 95 \\
\hline $19-4,109$ & 48.15 & 9.09 & 22.04 & 1.05 & 1.04 & 1.40 & 0.35 & n.d. & 2.50 & 112 & 118 & 31 & 32 & 79 & 1180 & 6 & 10 & 31 & 89 \\
\hline $21-1,90$ & 45.85 & 14.70 & 18.70 & 1.20 & 1.04 & 1.61 & 0.50 & n.d. & 2.29 & 96 & 160 & 59 & 70 & 140 & 830 & 12 & 19 & 28 & 130 \\
\hline $23-1,90$ & 29.65 & 4.02 & 35.92 & 0.96 & 0.68 & 0.93 & 0.15 & n.d. & 2.02 & 360 & 67 & 12 & 21 & 49 & 670 & 3 & 9 & 21 & 53 \\
\hline $24-3,94$ & 40.20 & 11.69 & 21.19 & 1.26 & 1.10 & 1.45 & 0.46 & n.d, & 3.75 & 100 & 130 & 49 & 100 & 135 & 960 & 17 & 22 & 38 & 130 \\
\hline $25-1,125$ & 37.65 & 12.52 & 26.08 & 1.35 & 1.08 & 1.35 & 0.47 & n.d. & 1.70 & 160 & 140 & 53 & 46 & 95 & 1180 & 5 & 19 & 37 & 130 \\
\hline $30-2,20$ & 38.65 & 11.10 & 25.05 & 1.22 & 0.98 & 1.73 & 0.48 & n.d. & 2.48 & 130 & 130 & 41 & 33 & 84 & 960 & n.d. & 25 & 33 & 120 \\
\hline $31-6,78$ & 43.00 & 16.24 & 21.20 & 1.18 & 0.95 & 1.80 & 0.68 & 0.20 & 2.22 & 250 & 110 & 73 & 54 & 125 & 690 & 12 & 23 & 37 & 130 \\
\hline $32-4,47$ & 36.70 & 13.23 & 26.45 & 1.17 & 0.90 & 1.50 & 0.57 & n.d. & 2.13 & 420 & 130 & 64 & 43 & 97 & 880 & 10 & 22 & 39 & 120 \\
\hline $33-4,62$ & 17.50 & 3.78 & 43.05 & 1.11 & 0.48 & 0.70 & 0.16 & n.d. & 1.10 & 570 & 120 & 11 & 34 & 28 & 460 & 22 & 11 & 33 & 42 \\
\hline $35-5,21$ & 20.40 & 7.20 & 35.99 & 1.75 & 0.48 & 1.38 & 0.29 & n.d. & 1.94 & 320 & 120 & 42 & 34 & 49 & 670 & 21 & 16 & 32 & 79 \\
\hline
\end{tabular}

during hydrolysis and crystallization in a basic chemical environment (Millot, 1964). An enrichment in Mn occurs from the first appearance of fibrous clays in Albian sediments to their quasi-disappearance after Oligocene time. The increase in Mn does not affect Site 402 which contains few or no fibrous clays. The Mn/fibrous clays relation, however, is not a direct one, because the sediments other than Albian and Paleocene/Eocene, poor in fibrous clays, are marked by manganiferous flow. It is, however, a deep water phenomenon because it is not encountered in the shallower Site 402.

\section{Local Diagenesis}

Although the argillaceous and chemical mineral components do not show any geochemical evolution with the depth of burial, there is suggestion of local and temporary diagenetic manifestations in the sedimentary sequences of Sites 399 to 402 .

The black shales facies of Aptian and Albian age is not characterized by a clayey assemblage distinct from more oxidized facies such as the ones from Paleocene to Eocene. Smectite, in particular, which is often fragile in an organic medium (Sigl et al., 1978) is as abundant and well crystallized in them as it is in other facies; irregular mixed-layers are rare or absent. There is consequently no perceptible modification of the argillaceous sequence in organic-rich surroundings which, themselves, show little change (Tissot et al., this volume). However, ionic mobilizations affect certain chemical elements such as Fe, $\mathrm{Mn}$, and $\mathrm{Ca}$, occurring in diffused concentrations, notably as carbonates (siderite, rhodochrosite, calcite, i.e., $400 \mathrm{~A}-74-1,95 \mathrm{~cm})$. It is consequently probable that the black shales facies, which has no effect on clay mineralogy, has a minor diagenetic influence on the dissolution, diffusion, and re-precipitation of carbonates and of some other minerals. Organic acids and decrease of the redox potential in specific zones (i.e., immediately in the neighborhood of black shales) favor Fe and Mn dissolution in bivalent state, and their precipitation in carbonate state when the precedent effects disappear.

No evidence of in-situ modification of minerals from volcanic origin exists in northern Biscay Bay. Although smectite and fibrous clays are independent of lithology and petrography, the zeolites and cristobalite encountered may have resulted from such an evolution. There is, however, no evidence that they are not associated with typically volcanic or hydrothermal mineral/geochemical components. 


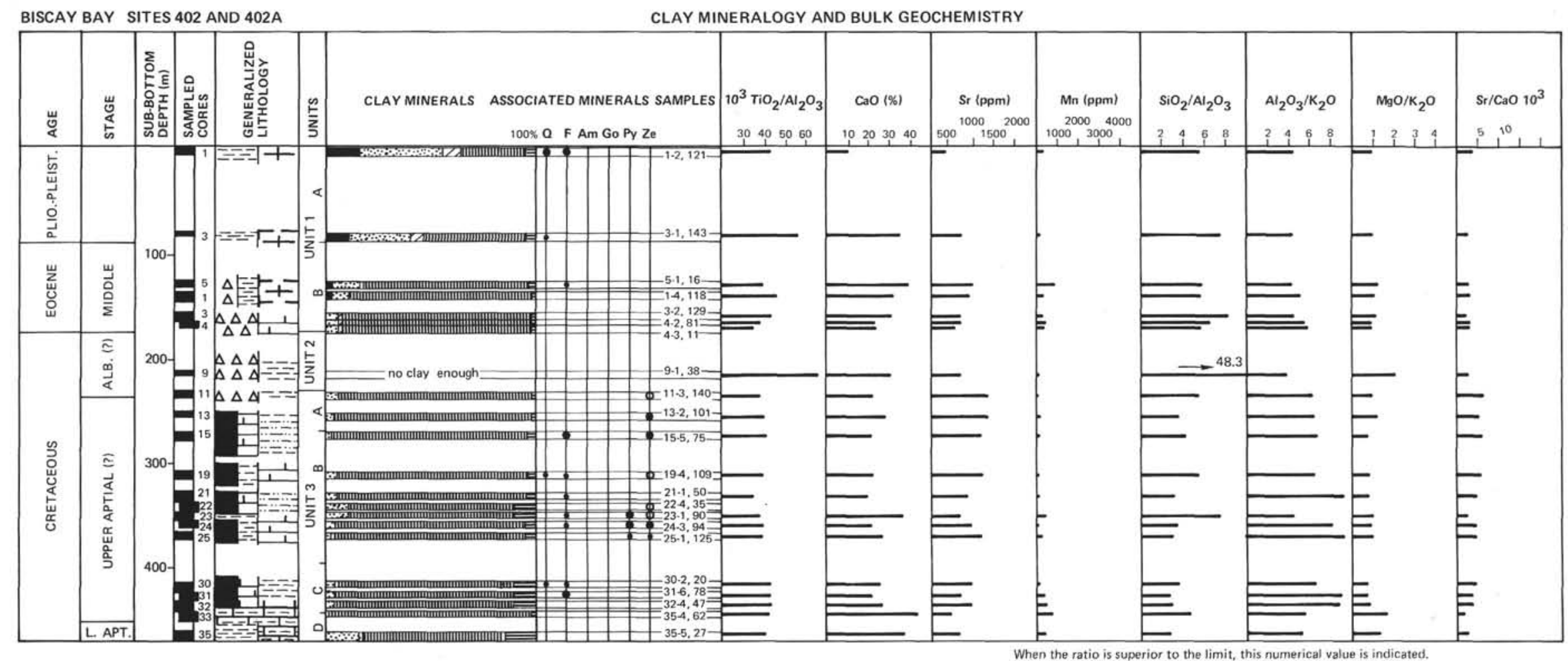

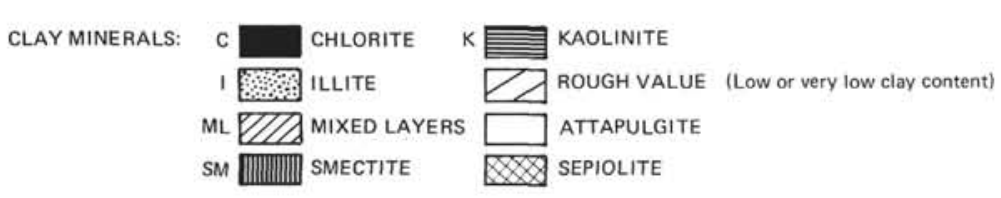

Figure 4. Site 402, clay mineralogy and bulk geochemistry.
ASSOCIATED MINERALS:

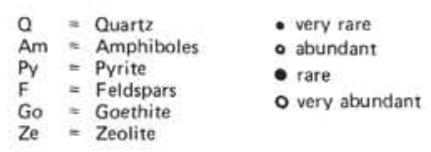

GEOCHEMICAL ANALYSES: 1/2: Two analyses for the same sample 
The fibrous clays, having a detrital aspect, probably originated in a chemically basic environment (Millot, 1964) in semiclosed marginal basins in Albian and Paleocene/Eocene times. Sediments formed in such basins were partially reworked owing to the instability of the subsident margins and thence deposited in the open oceanic environment. Some of the clinoptilolite and cristobalite may have had a similar origin because they too can form in basic and confined sedimentary environments and under conditions like those governing the formation of some smectites, attapulgites, and sepiolites (Sommer, 1972; Weaver and Beck, 1977). The increase in zeolites in Site 402 , which is the innermost and the least deep on the European margin, seems to favor this possibility. It is probable, however, that some of the zeolites and cristobalite originated in situ under conditions of dissolution and recrystallization of free silica and associated cations by local diagenesis (Wise and Kelts, 1972; Stonecipher, 1976; Mitsui and Taguchi, 1977; Kagami, this volume).

\section{Comparison Between the ThreeSites of North Biscay Bay}

From the shallowest Site 402 to the deepest Sites 399 and 400 an increase occurs in relatively small sized minerals of high buoyancy potential (smectite, fibrous clays) to the detriment of more rapidly deposited minerals (illite, chlorite, kaolinite, feldspars) (Figure 5). This indicates a differential settling offshore evoking a deltaic environment s. l. (Millot, 1964; Chamley, 1971; Gibbs, 1977), which is in agreement with other sedimentological observations (Auffret, this volume). Another cause of the scarcity of fibrous clay minerals at Site 402 could be a supply by relatively deep meridian currents originating from lower latitudes where these minerals are abundant on continents (Millot, 1964; Chamley, 1971; Chamley et al., in press). The difficulty to supply these minerals from the adjacent land masses must also be envisaged: fibrous minerals are poorly represented in the Armorican basins (EstéouleChoux, 1967), and the flat morphology of the large Basin of Paris where they are frequent (Sommer, 1969; Trauth et al., 1969; Trauth, 1974) does not favor their erosion and their transport toward the open sea.

From Site 402 to Site 400 , the differentiation between the three sites also manifests itself from a chemical point of view by decrease of carbonates and increase of transition elements $(\mathrm{Mn})$.

\section{ROCKALL PLATEAU - RESULTS}

\section{Site 403; Figure 6; Table 3}

\section{Upper Paleocene (?), Lower and Middle Eocene}

Lithologic Units 3 and 2 consist of arkosic sandstone, lapilli tuff and conglomerate, tuffaceous mudstone, and siliceous nannochalk. Smectite is predominant and well crystallized. Illite and kaolinite locally occur in traces. The geochemistry is characterized by the predominance of the siliceous phase $(\mathrm{Si}, \mathrm{Al}, \mathrm{Fe}, \mathrm{Mg}, \mathrm{Ti})$ in contrast with the calcitic one $(\mathrm{Ca}, \mathrm{Sr})$. An exception exists in $-40-1,5 \mathrm{~cm}$ where $\mathrm{Ca}$ is present in noticeable amounts, associated with $\mathrm{Mn}$ and $\mathrm{P}_{2} \mathrm{O}_{5}$. The ratios are as follows: $\mathrm{SiO}_{2} / \mathrm{Al}_{2} \mathrm{O}_{3}$ low, $\mathrm{MgO} / \mathrm{K}_{2} \mathrm{O}$ and $\mathrm{TiO}_{2} / \mathrm{Al}_{2} \mathrm{O}_{3}$ high, $\mathrm{Sr} / \mathrm{CaO}$ unstable. The lower Eocene sediments are rich in $\mathrm{Mg}, \mathrm{Fe}, \mathrm{V}$, and $\mathrm{Cr}$.
Alkaline and reducing sediments are suggested by the presence of rhodochrosite, carbonate-apatite, calcite, siderite, and glauconite.

\section{Oligocene}

In the upper part of lithologic Unit 2 the clay fraction is poor; slight increase in illite and kaolinite and the appearance of chlorite, zeolite, and irregular mixed-layers occur. $\mathrm{Mn}$ and $\mathrm{Al}_{2} \mathrm{O}_{3} / \mathrm{K}_{2} \mathrm{O}$ and $\mathrm{TiO}_{2} / \mathrm{Al}_{2} \mathrm{O}_{3}$ ratios decrease, whereas that of $\mathrm{SiO}_{2} / \mathrm{Al}_{2} \mathrm{O}_{3}$ increases; $\mathrm{Sr}$ carbonate and minor phosphate appear.

\section{Upper Miocene}

The base of Unit 1 (nannofossil ooze, marly ooze, calcareous mud) is poor in the clay fraction, and consists chiefly of smectite. The chemical composition is marked by high contents of $\mathrm{Ca}$ and $\mathrm{Sr}$, and a decrease of the $\mathrm{Si}$ phase and $\mathrm{Mg}$. A major change occurs between $-9-5,80 \mathrm{~cm}$ and $-9-4,129 \mathrm{~cm}$, with abrupt decrease of $\mathrm{Al}_{2} \mathrm{O}_{3}, \mathrm{Si}, \mathrm{Na}$, and quartz contents.

\section{Pliocene, Pleistocene}

In the upper part of Unit 1, a marly foram nannofossil ooze, the clay fraction becomes abundant and is marked by a steady upward increase in illite, chlorite, irregular mixed-layers, quartz, feldspars, amphiboles. $\mathrm{SiO}_{2}$ also increases, whereas a general decrease affects $\mathrm{CaO}, \mathrm{Sr}$, $\mathrm{SiO}_{2} / \mathrm{Al}_{2} \mathrm{O}_{3}, \mathrm{TiO}_{2} / \mathrm{Al}_{2} \mathrm{O}_{3}$, and $\mathrm{MgO} / \mathrm{K}_{2} \mathrm{O}$.

\section{Site 404; Figure 7; Table 3}

The same mineralogical and geochemical successions occur as in Site 403. A local enrichment in Mn (rhodochrosite) and $\mathrm{P}_{2} \mathrm{O}_{5}$ (apatite) contents is noted in Eocene sediments.

\section{Site 405; Figure 8; Table 4}

Although sparsely sampled, the site shows results close to those obtained for Site 406. Sediments of lower Eocene are peculiarly rich in $\mathrm{SiO}_{2}$ and also contain fairly high amounts of $\mathrm{Mn}$.

\section{Site 406; Figure 9; Table 4}

\section{Eocene}

Calcareous claystone, followed upward by marly limestone and siliceous and/or calcareous chalk, constitutes Unit 5 and the base of Unit 4 .

The clay mineral is nearly exclusively smectite, and is often accompanied by cristobalite. A geochemical break occurs between lower Eocene and middle/upper Eocene sediments (Cores 45 to 42 ); the lower Eocene has (1) high values of $\mathrm{Si}, \mathrm{Sr} / \mathrm{CaO}, \mathrm{Al}_{2} \mathrm{O}_{3} / \mathrm{K}_{2} \mathrm{O}, \mathrm{TiO}_{2} / \mathrm{Al}_{2} \mathrm{O}_{3}$, (2) moderate to low $\mathrm{Ca}$ content, (3) locally, simultaneous abundance of $\mathrm{Fe}$ and $\mathrm{Mg}$ (presence of hypersthene in -43-6, $47 \mathrm{~cm}$ ). Middle/upper Eocene sediments are high in carbonates, show a decrease of the above-mentioned ratios, an end to Mn metallization, and simultaneous disappearance of high $\mathrm{Fe}$ and $\mathrm{Mg}$ values.

\section{Oligocene, Early Miocene}

In the calcareous chalk of the top of Unit 4 and in the siliceous calcareous chalk and calcareous diatomite of Unit 


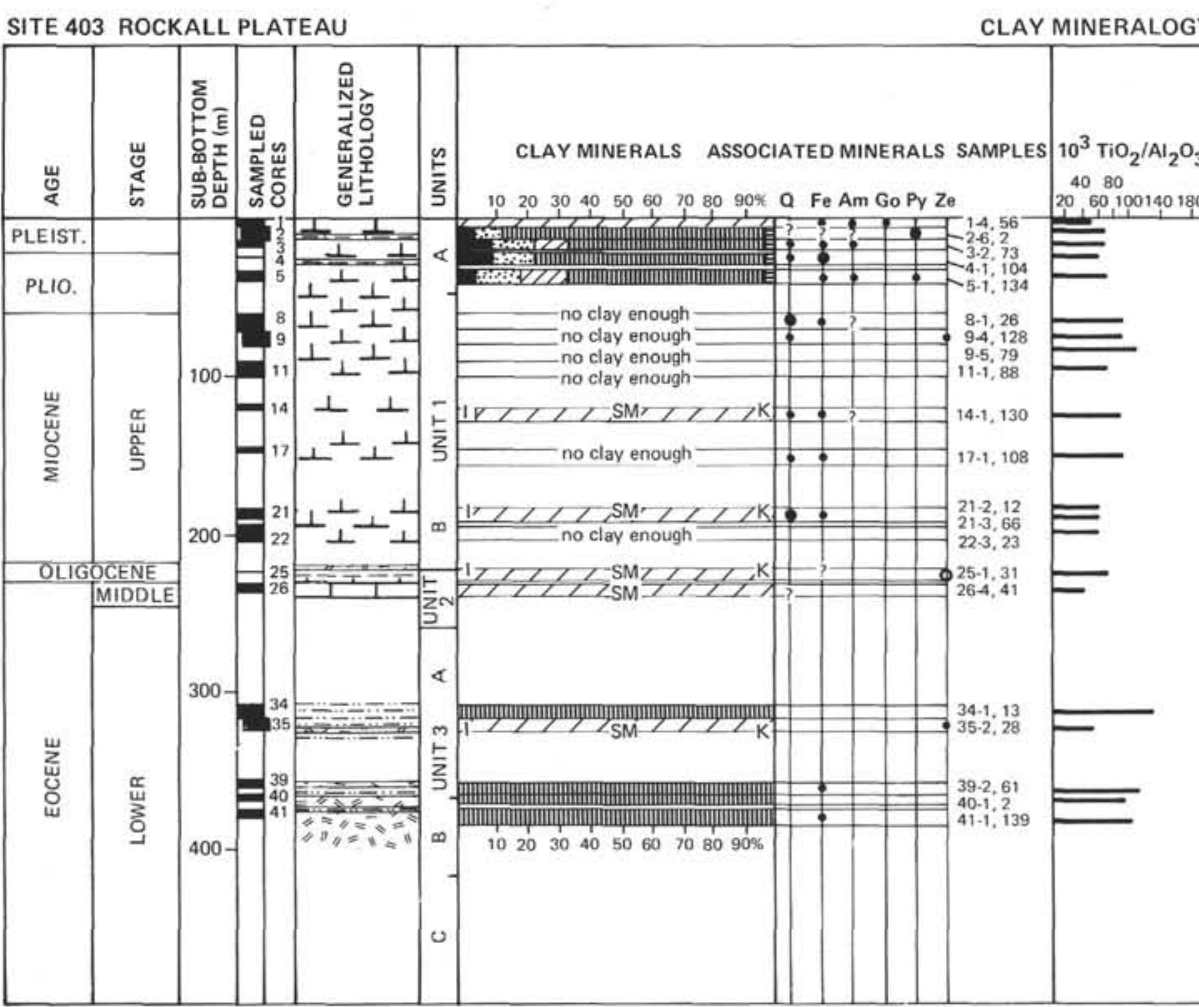

CLAYMINERALS

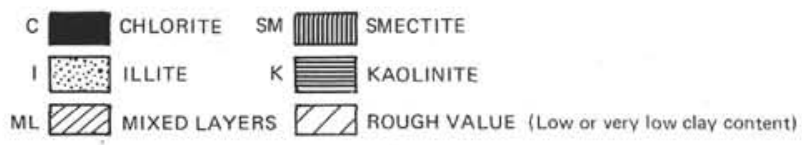

Figure 5. Site 403, clay mineralogy and bulk geochemistry.

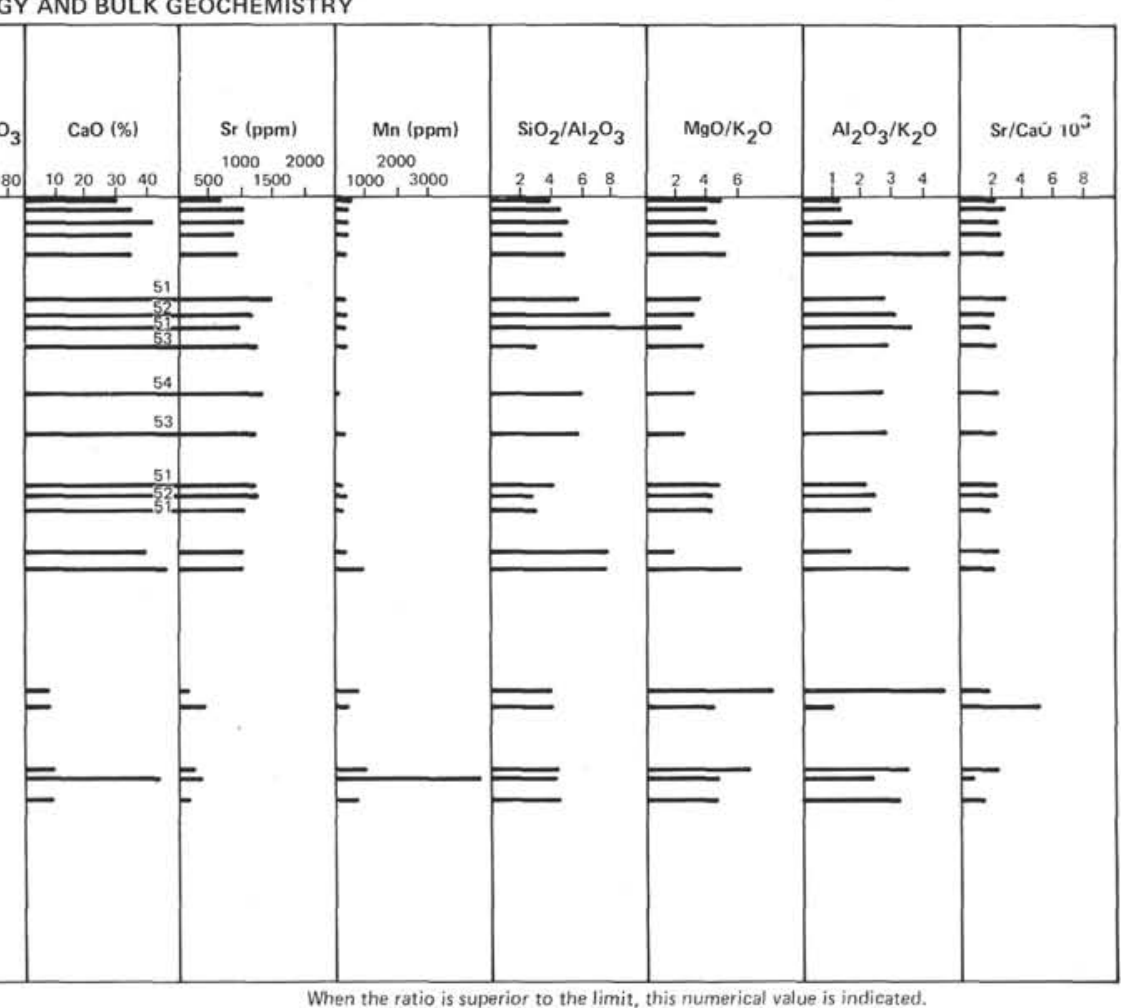

ASSOCIATED MINERALS

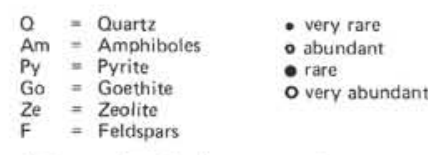

1: Two analyses for the same sample. 


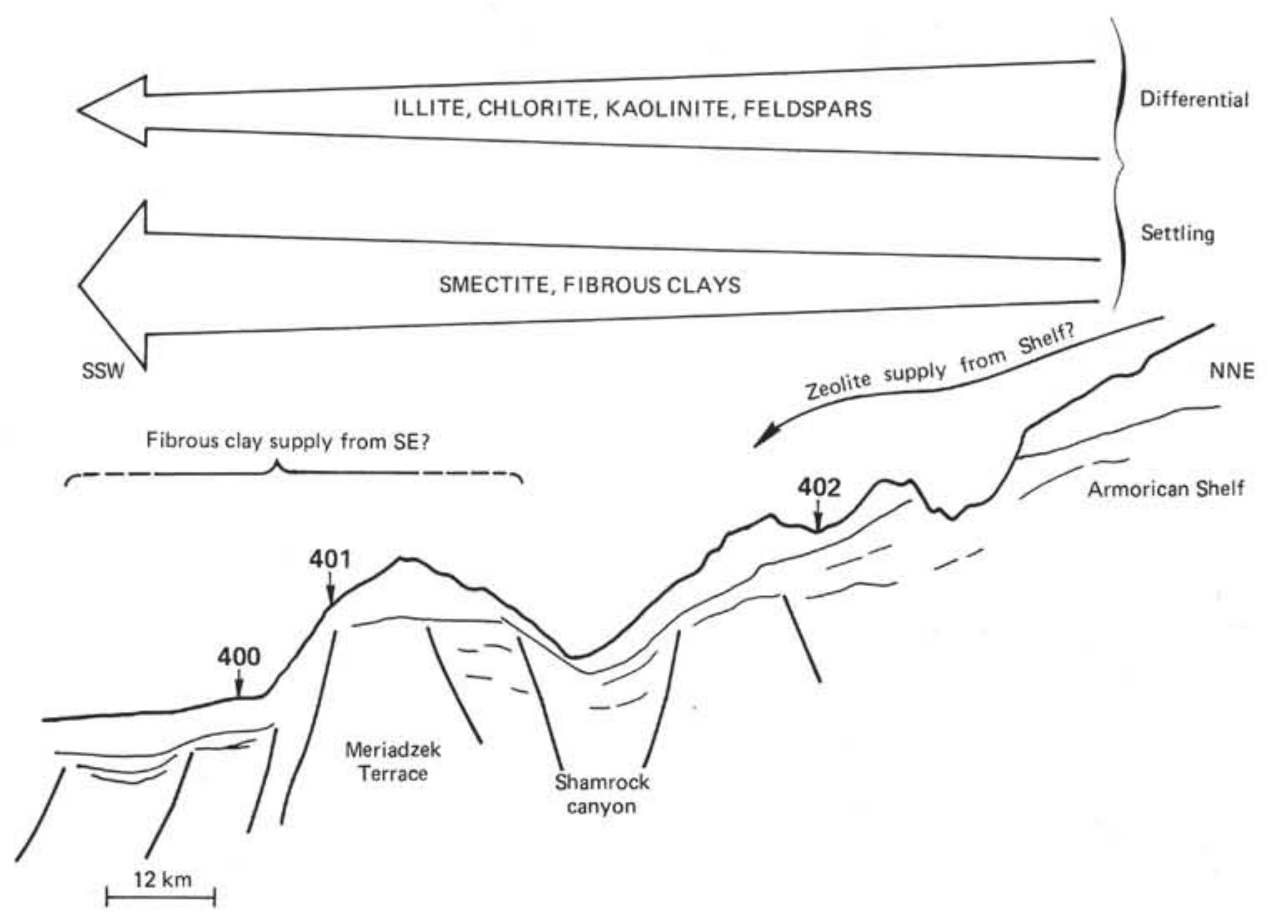

Figure 6. Origin and distribution of clay fraction components on the north of Biscay Bay margin.

TABLE 3

Geochemical Data, Sites 403 and 404

\begin{tabular}{|c|c|c|c|c|c|c|c|c|c|c|c|c|c|c|c|c|c|c|c|}
\hline \multirow{2}{*}{$\begin{array}{c}\text { Sample } \\
\text { (Interval in } \mathrm{cm} \text { ) }\end{array}$} & \multicolumn{9}{|c|}{$\overbrace{}^{\%}$} & \multicolumn{10}{|c|}{ ppm } \\
\hline & $\mathrm{SiO}_{2}$ & $\mathrm{Al}_{2} \mathrm{O}_{3}$ & $\mathrm{CaO}$ & $\mathrm{MgO}$ & $\mathrm{Na}_{2} \mathrm{O}$ & $\mathrm{K}_{2} \mathrm{O}$ & $\mathrm{TiO}_{2}$ & $\mathrm{P}_{2} \mathrm{O}_{5}$ & $\mathrm{Fe}$ & $\mathrm{Mn}$ & $\mathrm{Zn}$ & $\mathrm{Li}$ & $\mathrm{Ni}$ & $\mathrm{Cr}$ & $\mathrm{Sr}$ & Co & $\mathrm{Cu}$ & $\mathrm{Pb}$ & V \\
\hline \multicolumn{20}{|l|}{ Site 403} \\
\hline 14,67 & 29.15 & 7.32 & 30.85 & 1.78 & 3.18 & 1.50 & 0.36 & n.d. & 2.09 & 560 & 110 & 16 & 34 & 65 & 720 & 14 & 38 & 23 & 89 \\
\hline $2-6,3$ & 22.90 & 4.96 & 34.67 & 1.61 & 2.18 & 1.28 & 0.35 & n.d. & 2.22 & 450 & 75 & 14 & 29 & 46 & 1030 & 19 & 48 & 46 & 79 \\
\hline $3-2,74$ & 14.30 & 2.78 & 41.83 & 0.98 & 1.53 & 0.60 & 0.19 & n.d. & 0.94 & 510 & 54 & 5 & 18 & 30 & 1050 & 11 & 22 & 26 & 30 \\
\hline $4-1,105$ & 22.60 & 4.80 & 34.65 & 1.28 & 1.73 & 1.00 & 0.28 & n.d. & 1.45 & 380 & 54 & 10 & 25 & 26 & 900 & 12 & 24 & 21 & 45 \\
\hline $5-1,135$ & 20.75 & 4.38 & 35.00 & 1.31 & 1.65 & 0.93 & 0.29 & n.d. & 1.62 & 430 & 66 & 9 & 26 & 38 & 970 & 16 & 25 & 27 & 51 \\
\hline $8-1,27$ & 3.25 & 0.58 & 50.58 & 0.43 & 1.00 & 0.16 & 0.05 & n.d. & 0.29 & 330 & 33 & 2 & 19 & 25 & 1500 & 13 & 14 & 41 & 11 \\
\hline $9-4,129$ & 3.55 & 0.46 & 52.15 & 0.45 & 0.90 & 0.15 & 0.04 & n.d. & 0.28 & 460 & 53 & 3 & 27 & 24 & 1220 & 15 & 14 & 31 & 5 \\
\hline $9-5,80$ & 3.70 & 0.35 & 50.58 & 0.52 & 1.08 & 0.15 & 0.04 & n.d. & 0.36 & 390 & 42 & 3 & 26 & 25 & 1020 & 14 & 13 & 32 & 9 \\
\hline $11-1,89$ & 1.70 & 0.59 & 53.38 & 0.45 & 0.93 & 0.16 & 0.04 & n.d. & 0.31 & 400 & 34 & 3 & 21 & 19 & 1300 & 16 & 14 & 32 & 9 \\
\hline $14-1,131$ & 2.60 & 0.44 & 53.90 & 0.37 & 0.93 & 0.14 & 0.04 & n.d. & 0.18 & 210 & 30 & 2 & 15 & 16 & 1350 & 11 & 14 & 32 & 8 \\
\hline $17-1,109$ & 1.90 & 0.33 & 52.85 & 0.35 & 0.90 & 0.13 & 0.03 & n.d. & 0.15 & 360 & 37 & 1 & 16 & 27 & 1230 & 11 & 12 & 41 & 11 \\
\hline $21-2,13$ & 3.75 & 0.90 & 51.45 & 0.40 & 0.98 & 0.19 & 0.05 & n.d. & 0.31 & 280 & 47 & 3 & 25 & 23 & 1240 & 15 & 8 & 36 & 13 \\
\hline $21-3,67$ & 1.90 & 0.65 & 51.98 & 0.36 & 0.75 & 0.15 & 0.04 & n.d. & 0.25 & 400 & 46 & 2 & 18 & 27 & 1300 & 11 & 13 & 37 & 15 \\
\hline $22-3,24$ & 3.05 & 0.99 & 50.75 & 0.50 & 0.94 & 0.23 & 0.06 & n.d. & 0.37 & 280 & 34 & 3 & 24 & 29 & 1030 & 15 & 24 & 33 & 9 \\
\hline $25-1,32$ & 16.35 & 2.13 & 40.36 & 1.74 & 1.50 & 1.11 & 0.14 & 0.89 & 2.48 & 380 & 140 & 20 & 89 & 52 & 1030 & 35 & 28 & 33 & 79 \\
\hline $26-4,43$ & 8.95 & 1.18 & 45.50 & 0.65 & 1.25 & 0.19 & 0.05 & n.d. & 0.61 & 960 & 46 & 8 & 31 & 15 & 1050 & 13 & 16 & 44 & 4 \\
\hline $34-1,15$ & 48.50 & 48.50 & 7.82 & 6.70 & 3.55 & 1.50 & 1.55 & n.d. & 7.80 & 800 & 99 & 22 & 63 & 140 & 160 & 52 & 100 & 4 & 320 \\
\hline $35-2,28$ & 56.80 & 14.29 & 8.93 & 3.32 & 3.68 & 3.25 & 0.65 & n.d. & 4.33 & 470 & 71 & 33 & 38 & 130 & 460 & 21 & 28 & 9 & 120 \\
\hline $39-2,63$ & 49.50 & 11.57 & 10.00 & 5.75 & 2.95 & 1.73 & 1.30 & n.d. & 7.00 & 1010 & 120 & 27 & 47 & 110 & 240 & 36 & 61 & 7 & 270 \\
\hline $40-1,5$ & 12.75 & 3.07 & 42.64 & 1.48 & 0.88 & 0.65 & 0.28 & n.d. & 2.14 & 4750 & 86 & 8 & 24 & 26 & 330 & 18 & 17 & 26 & 68 \\
\hline $41-4,140$ & 47.45 & 10.75 & 8.85 & 7.31 & 4.45 & 2.38 & 1.04 & n.d. & 9.68 & 750 & 110 & 7 & 56 & 110 & 140 & 44 & 94 & 7 & 300 \\
\hline \multicolumn{20}{|l|}{ Site 404} \\
\hline $11-2,76$ & 7.40 & 1.32 & 46.20 & 0.59 & 1.45 & 0.34 & 0.10 & n.d. & 0.47 & 410 & 34 & 2 & 17 & 33 & 1120 & 10 & 18 & 39 & 12 \\
\hline $4-2,102$ & 1.80 & 0.63 & 52.85 & 0.42 & 0.93 & 0.14 & 0.04 & n.d. & 0.25 & 400 & 36 & 3 & 21 & 23 & 1190 & 12 & 18 & 33 & 12 \\
\hline $7-1,20$ & 57.50 & 4.96 & 16.42 & 1.78 & 2.60 & 0.65 & 0.64 & n.d. & 2.88 & 450 & 84 & 24 & 45 & 79 & 330 & 16 & 35 & 20 & 170 \\
\hline $10-1,65$ & 47.40 & 6.61 & 21.67 & 3.66 & 2.30 & 0.43 & 1.05 & n.d. & 3.70 & 950 & 79 & 18 & 52 & 91 & 450 & 33 & 44 & 14 & 190 \\
\hline $16-1,115$ & 43.20 & 8.27 & 20.61 & 4.70 & 2.28 & 1.30 & 0.63 & n.d. & 4.55 & 670 & 170 & 17 & 89 & 130 & 460 & 35 & 47 & 17 & 195 \\
\hline $17-5,18$ & 31.15 & 6.38 & 27.11 & 3.83 & 1.58 & 1.00 & 0.19 & 1.13 & 5.00 & 9250 & 116 & 15 & 36 & 57 & 180 & 29 & 65 & 11 & 190 \\
\hline $21-2,132$ & 25.25 & 4.72 & 32.51 & 3.66 & 1.73 & 1.08 & 0.15 & 3.72 & 3.80 & 7300 & 91 & 15 & 44 & 71 & 310 & 32 & 34 & 18 & 130 \\
\hline
\end{tabular}


SITE 404 ROCKALL PLATEAU

MINERALOGICAL AND GEOCHEMICAL BULK

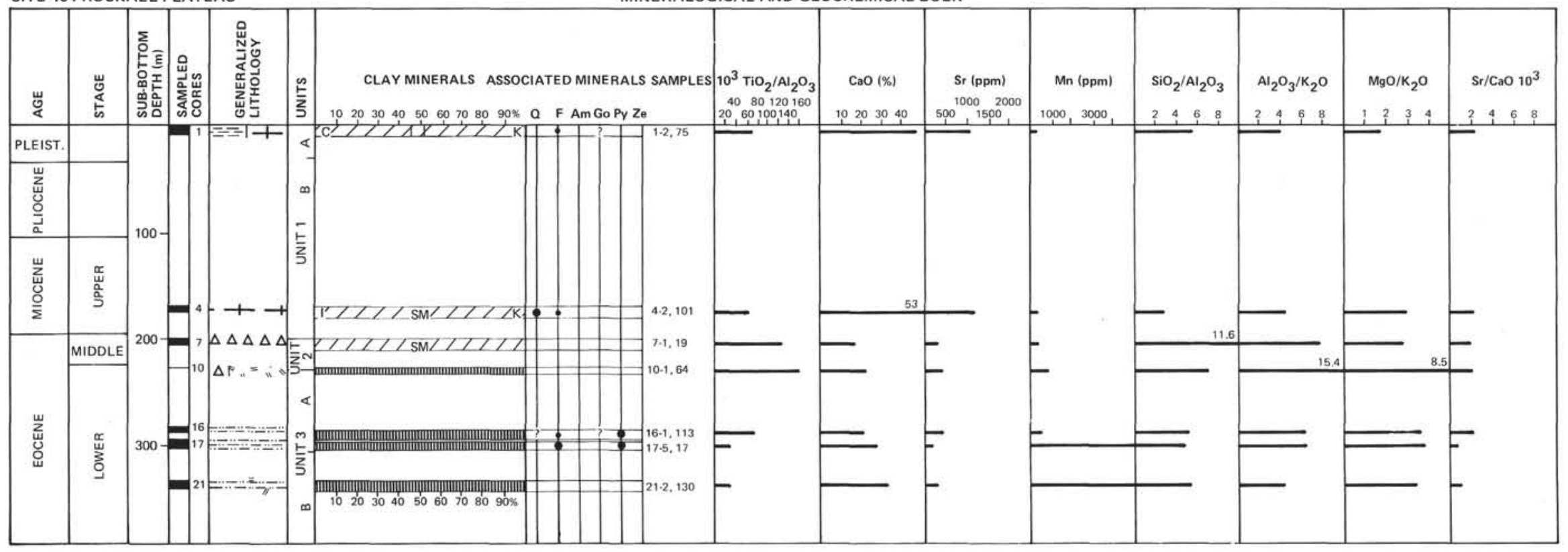

CLAY MINERALS:

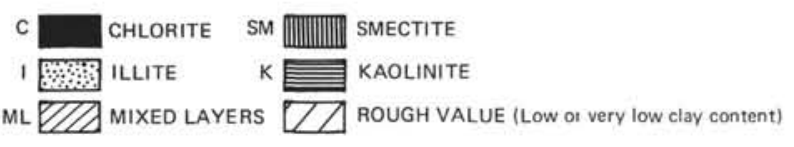

1 CHLoRIte SM

ML MIXEd LAYERS $\square \triangle$ ROUGH VALue (Low ot very low clay content)

Figure 7. Site 404, clay mineralogy and bulk geochemistry.
ASSOCIATED MINERALS

$\begin{array}{rlrl}\mathrm{O} & =\text { Quartz } & & \text { very rare } \\ \text { Am } & =\text { Amphiboles } & & \text { a abundant } \\ \mathrm{Py} & =\text { Pyrite } & & \text { rare } \\ \mathrm{F} & =\text { Feldspars } & \text { O very abundant } \\ \text { Go } & =\text { Geothite } & & \\ \mathrm{Ze} & =\text { Zeolite } & & \end{array}$ 
SITE 405 ROCKALL PLATEAU

CLAY MINERALOGY AND BULK GEOCHEMISTRY

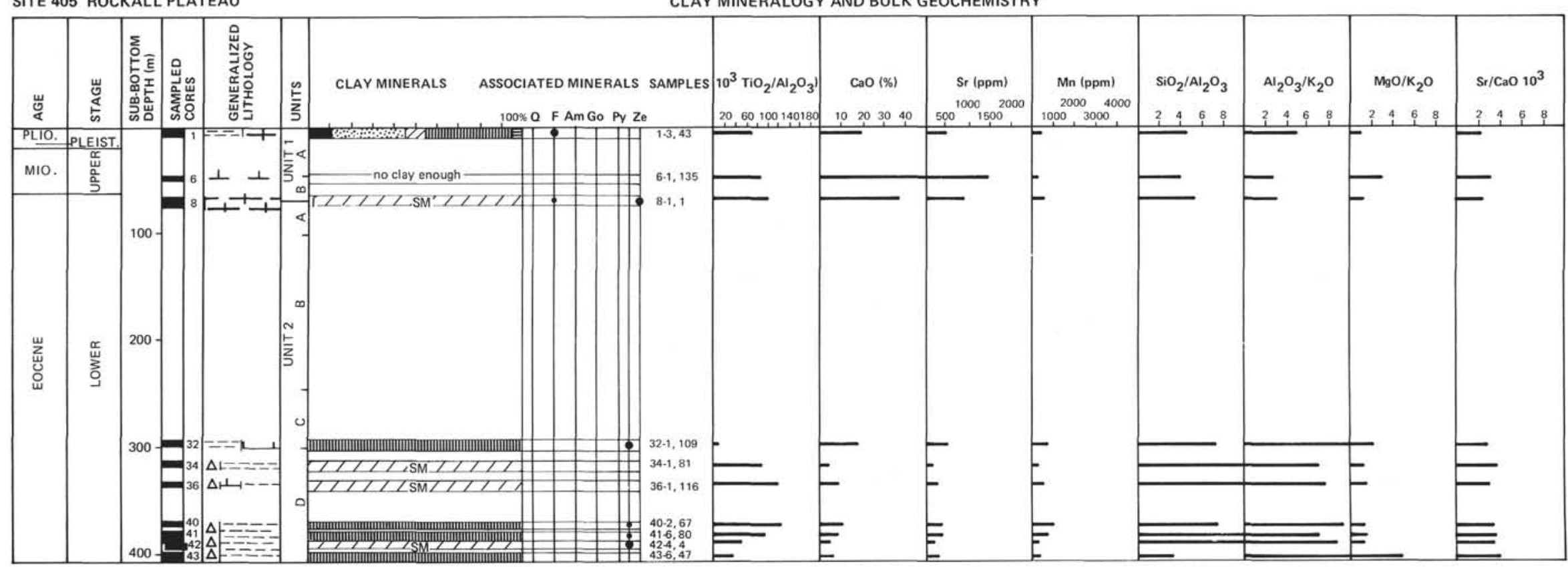

CLAY MINERALS:

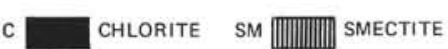

1 ILITE K K

ML UIA Mixed LAYERS $\square \backslash$ ROUGH VALUE (Low or very low clay content)

Figure 8. Site 405, clay mineralogy and bulk geochemistry.
ASSOCIATED MINERALS:

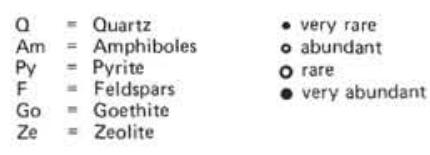


TABLE 4

Geochemical Data, Sites 405 and 406

\begin{tabular}{|c|c|c|c|c|c|c|c|c|c|c|c|c|c|c|c|c|c|c|c|}
\hline \multirow{2}{*}{$\begin{array}{c}\text { Sample } \\
\text { (Interval in } \mathrm{cm} \text { ) }\end{array}$} & \multicolumn{9}{|c|}{$\%$} & \multicolumn{8}{|c|}{$\underbrace{\mathrm{ppm}}$} & \multirow[b]{2}{*}{$\mathrm{Pb}$} & \multirow[b]{2}{*}{$\mathrm{V}$} \\
\hline & $\mathrm{SiO}_{2}$ & $\mathrm{Al}_{2} \mathrm{O}_{3}$ & $\mathrm{CaO}$ & $\mathrm{MgO}$ & $\mathrm{Na}_{2} \mathrm{O}$ & $\mathrm{K}_{2} \mathrm{O}$ & $\mathrm{TiO}_{2}$ & $\mathrm{P}_{2} \mathrm{O}_{5}$ & $\mathrm{Fe}$ & $\mathrm{Mn}$ & $\mathrm{Zn}$ & $\mathrm{Li}$ & $\overrightarrow{\mathrm{Ni}}$ & $\mathrm{Cr}$ & $\mathrm{Sr}$ & Co & $\mathrm{Cu}$ & & \\
\hline \multicolumn{20}{|l|}{ Site 405} \\
\hline $1-3,43$ & 39.55 & 8.50 & 19.32 & 1.87 & 2.48 & 1.73 & 0.45 & n.d. & 2.26 & 480 & 42 & 15 & 33 & 73 & 450 & 15 & 23 & 33 & 58 \\
\hline $6-1,139$ & 1.40 & 0.35 & 49.70 & 0.37 & 0.68 & 0.13 & 0.03 & n.d. & 0.20 & 270 & 5 & 2 & 40 & 35 & 1470 & 16 & 6 & 35 & n.d. \\
\hline $8-1,1$ & 14.70 & 2.68 & 37.63 & 1.12 & 1.48 & 0.85 & 0.28 & n.d. & 2.57 & 600 & 52 & 9 & 51 & 53 & 900 & 16 & 18 & 31 & 29 \\
\hline $32-1,109$ & 53.15 & 7.32 & 18.33 & 1.74 & 1.85 & 0.75 & 0.09 & n.d. & 3.50 & 770 & 180 & 7 & 45 & 48 & 510 & 39 & 72 & 6 & 120 \\
\hline $34-1,81$ & 78.70 & 2.78 & 4.55 & 0.54 & 0.75 & 0.40 & 0.25 & n.d. & 1.35 & 270 & n.d. & 2 & 79 & 61 & 170 & 52 & 4 & 6 & 21 \\
\hline $36-1,116$ & 70.40 & 3.56 & 8.68 & 0.75 & 1.03 & 0.46 & 0.43 & n.d. & 2.06 & 540 & 160 & 4 & 49 & 64 & 260 & 12 & 16 & 27 & 63 \\
\hline $40-2,67$ & 55.60 & 7.44 & 11.03 & 1.45 & 1.73 & 0.79 & 0.94 & n.d. & 4.00 & 1080 & 47 & 9 & 41 & 73 & 380 & 12 & 36 & 17 & 280 \\
\hline $41-6,80$ & 67.45 & 4.37 & 8.40 & 1.01 & 1.73 & 0.62 & 0.42 & n.d. & 2.66 & 730 & 34 & 5 & 59 & 62 & 310 & 21 & 46 & 13 & 47 \\
\hline $42-4,4$ & 80.45 & 2.56 & 4.62 & 0.67 & 0.86 & 0.50 & 0.23 & n.d. & 1.87 & 290 & 160 & 4 & 280 & 57 & 160 & 49 & 29 & 30 & 32 \\
\hline $43-6,47$ & 50.60 & 15.12 & 6.82 & 2.98 & 2.45 & 0.60 & 0.55 & n.d. & 4.95 & 340 & 16 & 17 & 61 & 55 & 270 & n.d. & 35 & 10 & 100 \\
\hline \multicolumn{20}{|l|}{ Site 406} \\
\hline $1-1,32$ & 41.65 & 12.99 & 12.71 & 2.53 & 2.49 & 2.58 & 0.75 & n.d. & 3.57 & 510 & 74 & 29 & 38 & 96 & 320 & 20 & 25 & 29 & 130 \\
\hline $2-4,125$ & 54.75 & 14.23 & 5.43 & 2.20 & 2.49 & 2.73 & 0.75 & n.d. & 4.31 & 360 & 49 & 32 & 59 & 91 & 290 & 19 & 20 & 21 & 150 \\
\hline $4-1,70$ & 1.10 & 0.32 & 52.50 & 0.31 & 0.76 & 0.13 & 0.03 & n.d. & 0.17 & 320 & 15 & 1 & 44 & 34 & 1480 & 12 & 6 & 33 & 11 \\
\hline $7-1,30$ & 4.20 & 1.15 & 49.70 & 0.41 & 0.70 & 0.28 & 0.07 & n.d. & 0.39 & 540 & 7 & 4 & 46 & 42 & 1500 & 14 & 4 & 35 & 16 \\
\hline $8-5,56$ & 3.90 & 1.02 & 48.37 & 0.37 & 0.70 & 0.24 & 0.06 & n.d. & 0.40 & 600 & 14 & 4 & 50 & 49 & 1420 & 17 & 12 & 35 & n.d. \\
\hline $10-1,24$ & 2.45 & 0.60 & 49.70 & 0.33 & 0.65 & 0.16 & 0.04 & n.d. & 0.24 & 510 & 6 & 3 & 49 & 17 & 1430 & 15 & 8 & 63 & 11 \\
\hline $13-2,71$ & 3.15 & 0.91 & 48.65 & 0.36 & 0.63 & 0.19 & 0.0 & n.d. & 0.30 & 550 & 6 & 4 & 51 & 48 & 1480 & 14 & 11 & 36 & n.d. \\
\hline $14-1,117$ & 6.05 & 1.56 & 45.33 & 0.46 & 0.64 & 0.34 & 0.0 & n.c & 0.5 & 490 & 6 & 6 & 55 & 39 & 1530 & 16 & 7 & 33 & 16 \\
\hline $16-1,85$ & 2.50 & 0.58 & 50.58 & 0.32 & 0.63 & 0.16 & 0.03 & n.d. & 0.24 & 420 & 6 & 3 & 42 & 25 & 1450 & 14 & 7 & 34 & 5 \\
\hline $22-1,25$ & 6.40 & 1.07 & 46.55 & 0.41 & 0.81 & 0.24 & 0.0 & n.d. & 0.49 & 1200 & 35 & 4 & 55 & 38 & 1490 & 13 & 9 & 34 & 5 \\
\hline $23-2,130$ & 12.35 & 2.31 & 41.65 & 0.62 & 0.84 & 0.46 & 0.1 & n. & 0.8 & 1000 & 62 & 9 & 63 & 48 & 1540 & 18 & 30 & 32 & 16 \\
\hline $24-1,95$ & 26.50 & 5.16 & 28.60 & 1.20 & 1.11 & 1.04 & 0.28 & 0.30 & 1.85 & 280 & 150 & 26 & 95 & 58 & 1200 & 32 & 25 & 26 & 63 \\
\hline $27-1,20$ & .45 & 0.89 & 23.00 & 0.29 & 1.11 & 0.20 & 0.0 & n.d. & 0.3 & 68 & 8 & 2 & 15 & 26 & 83 & 4 & 1 & 25 & n.d. \\
\hline $28-2,7$ & 1.35 & & 27.13 & 0.32 & 1.91 & 0.20 & 0.0 & & 0.3 . & 97 & 23 & 3 & 19 & 48 & & 4 & 6 & 18 & n.d. \\
\hline $29-4,130.1^{\mathrm{a}}$ & 27.50 & 1.75 & 34.65 & 0.53 & 0.98 & 0.38 & $\begin{array}{l}0.084 \\
0.08\end{array}$ & $\begin{array}{l}\text { n.d. } \\
\text { n.d. }\end{array}$ & 0.67 & 270 & 120 & 9 & 36 & 27 & 1080 & 7 & 20 & 48 & 32 \\
\hline $29-4,130.2^{\mathrm{a}}$ & 2.95 & 2.60 & 29.22 & 0.65 & $\begin{array}{l}1.28 \\
1.28\end{array}$ & 0.49 & 0.12 & n.d. & 0.92 & 210 & 110 & 5 & 55 & 47 & 1230 & 9 & 26 & 32 & 37 \\
\hline $30-2,14$ & .70 & 1.42 & 43.05 & 0.4 & 0.86 & & 0.0 & & 0.4 & 310 & 73 & 5 & 44 & 29 & 1090 & 9 & 4 & 26 & 16 \\
\hline $31-3,55$ & 11.30 & 1.60 & 43.75 & 0.56 & 0.78 & 0.30 & 0.08 & n.d & 0.57 & 570 & 116 & 5 & 66 & 27 & 1110 & 12 & 35 & 33 & 16 \\
\hline $32-4,70$ & .00 & 2.24 & 35.70 & 0.6 & 1.05 & 0.40 & 0.13 & & 0.86 & 600 & 45 & 9 & 37 & 35 & 1050 & 9 & 10 & 25 & 16 \\
\hline $33-4,67$ & 13.50 & 2.92 & 39.55 & 0.85 & 0.63 & 0.46 & 0.1 . & n.d. & 1.12 & 610 & 19 & 8 & 52 & 47 & 1100 & 13 & 18 & 28 & 21 \\
\hline $35-2,30$ & 5.50 & 0.93 & 49.00 & 0.41 & 0.46 & 0.19 & 0.05 & n.d. & 0.45 & 680 & 16 & 3 & 49 & 21 & 1270 & 13 & 2 & 33 & 5 \\
\hline $36-2,53$ & 18.25 & & 36.93 & 1.0 & 0.79 & 0.68 & 0.1 & & 2.2 & 520 & 67 & 8 & 88 & 55 & 89 & 21 & 6 & 27 & 42 \\
\hline $37-3,137$ & 5.70 & 0.96 & 47.95 & 0.4 & 0.40 & 0.21 & 0.0 & n.d. & 0.52 & 660 & 65 & 66 & 32 & 24 & 1030 & 11 & 8 & 32 & 16 \\
\hline $38-3,77$ & 12.35 & 0.83 & 43.58 & 0.5 & 0.40 & 0.14 & 0.0 & n.d. & 0.45 & 570 & 8 & 4 & 32 & 40 & 710 & 11 & 9 & 28 & n.d. \\
\hline $39-4,13$ & & 4.13 & 29.61 & 1.04 & 0.71 & 0.56 & 0.18 & 0.17 & 1.11 & 380 & 130 & 130 & 110 & 47 & 77 & 17 & 52 & 22 & 42 \\
\hline $40-3,33$ & 13.85 & 1.75 & 42.80 & 0.58 & 0.43 & 0.24 & 0.07 & n. & 0.60 & 540 & 92 & 68 & 43 & 28 & 920 & 8 & 16 & 32 & 21 \\
\hline $41-4,80$ & 8.15 & 1.50 & 46.37 & 0.5 & 0.38 & 0.23 & 0.0 & n. & 0.60 & 630 & 123 & 3 & 45 & 25 & 1130 & 12 & 14 & 25 & 21 \\
\hline $42-3,101$ & 9.45 & 1.00 & 45.50 & 0.41 & 0.46 & 0.15 & 0.06 & n.c & 0.42 & 740 & 42 & 2 & 34 & 24 & 1090 & 12 & 11 & 32 & 5 \\
\hline $45-4,38$ & 7.65 & 1.06 & 46.37 & 0.41 & 0.50 & 0.16 & 0.05 & n. & 0.28 & 3500 & 62 & 2 & 46 & 14 & 1210 & 9 & 18 & 140 & 16 \\
\hline $46-1,8$ & 40.30 & 8.27 & 14.88 & 2.49 & 1.73 & 1.23 & 0.64 & n. & 7.14 & 930 & 74 & 27 & 68 & 58 & 1000 & 26 & 34 & 23 & 205 \\
\hline $47-1,63$ & 39.20 & 9.21 & 19.43 & 1.82 & 1.45 & 0.78 & 0.71 & n.d. & 3.60 & 1400 & 48 & 12 & 70 & 91 & 940 & 31 & 68 & 25 & 170 \\
\hline $48-1,40$ & 39.80 & 8.74 & 17.50 & 1.64 & 1.39 & 0.70 & 0.7 & n. & 3.6 & 1500 & 86 & 7 & 58 & 97 & 930 & 25 & 82 & 25 & 130 \\
\hline $49-1,75$ & 37.05 & 8.26 & 22.33 & 1.76 & 1.23 & 0.61 & 0.48 & n.d. & 3.50 & 1600 & 135 & 6 & 76 & 91 & 980 & 35 & 86 & 64 & 120 \\
\hline $49-2,31$ & 37.95 & 7.32 & 21.18 & 1.45 & 1.19 & 0.63 & 0.67 & n.d. & 3.29 & 3400 & 64 & 5 & 63 & 42 & 930 & 23 & 53 & 28 & 97 \\
\hline
\end{tabular}

${ }^{\mathrm{a}}$ Heterogeneous sample, two analyses.

3 , clay is rare and is characterized by smectite, locally accompanied by traces of illite and kaolinite. The geochemistry is heterogeneous, with a high $\mathrm{SiO}_{2} / \mathrm{Al}_{2} \mathrm{O}_{3}$ ratio due to free silica (diatoms); transition elements disappear.

\section{Middle and Upper Miocene}

The nannofossil chalk and nannofossil ooze of Unit 2 contain few clay minerals. Smectite is in excess of chlorite and illite, but the latter minerals increase upwards. The rather homogeneous chemical composition is marked by little $\mathrm{SiO}_{2}$ and $\mathrm{Mn}$, and much carbonate. A local phosphate occurrence and an increase of Mn content occurs at the early/middle Miocene boundary.

\section{Pliocene, Pleistocene}

In the marly foraminiferous nannofossil ooze of Unit 1 the clay assemblage becomes diversified and includes chlorite, illite, irregular mixed-layers (chiefly illite- smectite, little chlorite-smectite), smectite (fairly well crystallized), kaolinite, accompanied by quartz and feldspars. $\mathrm{SiO}_{2}$ increases whereas $\mathrm{CaO}$ decreases.

\section{DISCUSSION}

Because of the limited sampling of Sites 404 and 405, the following discussion is based mainly on data from Sites 403 and 406.

\section{Origin of the Principal Mineral and Chemical Phases}

In the sediments deposited from Paleocene to lower Miocene time nearly all of the clay is usually wellcrystallized smectite. Fe and $\mathrm{Mg}$ are relatively abundant and are commonly associated with cristobalite/tridymite and sometimes zeolites which suggest a source rich in the vitreous and mineral elements of volcanic origin (Harrison et al., this volume; Harding, this volume; Latouche, this volume; see also Site Chapters, this volume). $\mathrm{Fe}$ and $\mathrm{Mg}$ do not generally occur as oxides, sulfides, 


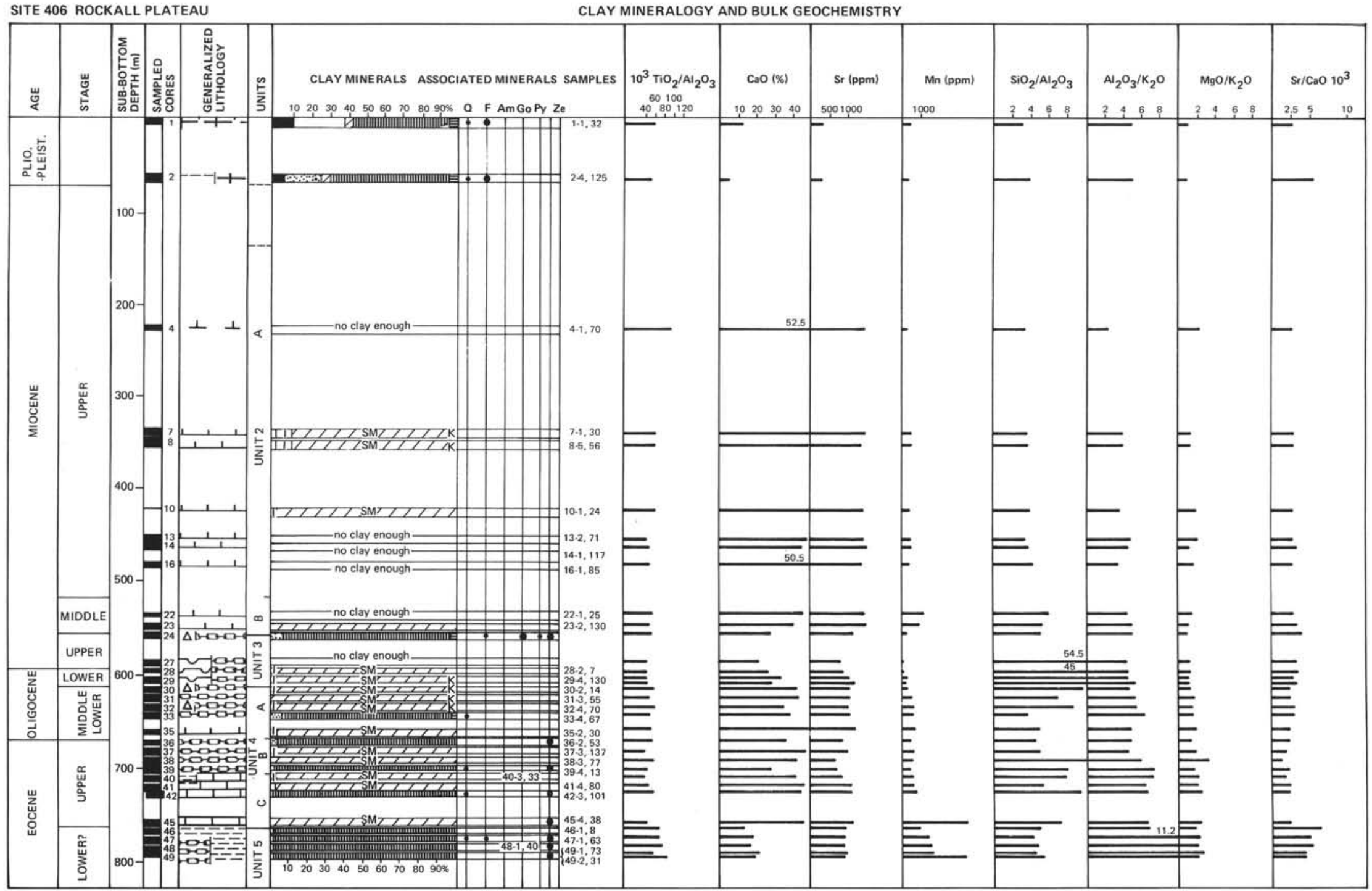

CLAY MINERALS:
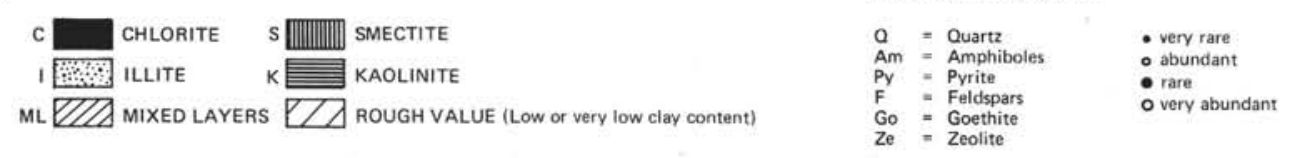

GEOCHEMICAL ANALYSES: 1/2: Two analyses for the same sample 
carbonates, or ferromagnesian sandy minerals and consequently are incorporated mainly in the smectite lattice as shown by differential thermal analysis curves. Such smectites suggest, at least partially, a volcanic origin. Such a hypothesis is supported by titanium enrichment (Rankama and Sahama, 1950), especially in the Eocene sediments of the Rockall area (Figure 10). Furthermore, the rare-earth elements examined by C. Courtois (University of Paris XI) are marked by a noticeable poverty in light elements (lanthanium, cerium, neodyme, samarium) in comparison to heavy elements (europium, terbium, yterbium, lutetium). Such a composition, which is not in equilibrium with that of seawater and cannot be of purely sedimentary origin, is close to the composition of a tholeiitic basalt. It is therefore highly probable that the smectite and other associated chemical elements resulted from the transformation of volcanic ash and glass rather than being derived as detritus from the weathering of sedimentary rocks.

An indeterminable part of the smectite, however, may be of remote origin, either pedologic or sedimentary, as shown by the occasional presence of detrital minerals such as kaolinite, illite, and chlorite. A non-volcanic origin is probable in those Eocene and Oligocene levels that are marked by a decrease in Fe, Mg, Ti (Table 4).

Whether the smectite formed in a submarine or subaerial environment is questionable. The composition of the rare-earth elements (in Sample 405-43-6, $47 \mathrm{~cm}$ ) is not in equilibrium with that of typical seawater which does not favor a submarine genesis. The active volcanism during the Paleogene, and particularly in the Eocene, probably produced volcanic areas exposed to subaerial alteration. The authors are inclined to favor a subaerial genesis for the smectite, followed by its erosion and deposition in the sea along with the other components, including pelagic carbonates, silica, and/or volcaniclastics.

Sites 405 and 406 are marked generally by more carbonates, less clay, and larger amounts of smectite and cristobalite/tridymite than at Sites 403 and 404. This suggests that sedimentation was generally more pelagic in the Paleogene in the Site 405-406 area than at Sites 403 and 404. In Figure 11 the mean compositions for Sites 403 and 404 are more closely related to the $\mathrm{MgO}$ and $\mathrm{F}_{2} \mathrm{O}_{3}$ poles than are those of Sites 405 and 406; this suggests closer proximity of Sites 403 and 404 to volcanic sources which is the sign of a strong volcanic influence.

\section{Climates and Currents}

Mineralogical and chemical changes, announced in Oligocene time, develop in the Miocene and particularly in the Pleistocene: primary detrital minerals or those from moderate continental alteration (mixed-layers) gradually replace smectite whereas carbonates and associate chemical elements increase. That change indicates a decrease in volcanic activity accompanied by a general modification of climatic conditions. The step-by-step cooling took place from late Paleogene onwards (see also Létolle and Vergnaud-Grazzini, this volume) and favors direct continental erosion of rocks, and the development of large meridian currents and calcareous planktonic communities. Pelagic sedimentation developed after the sinking of

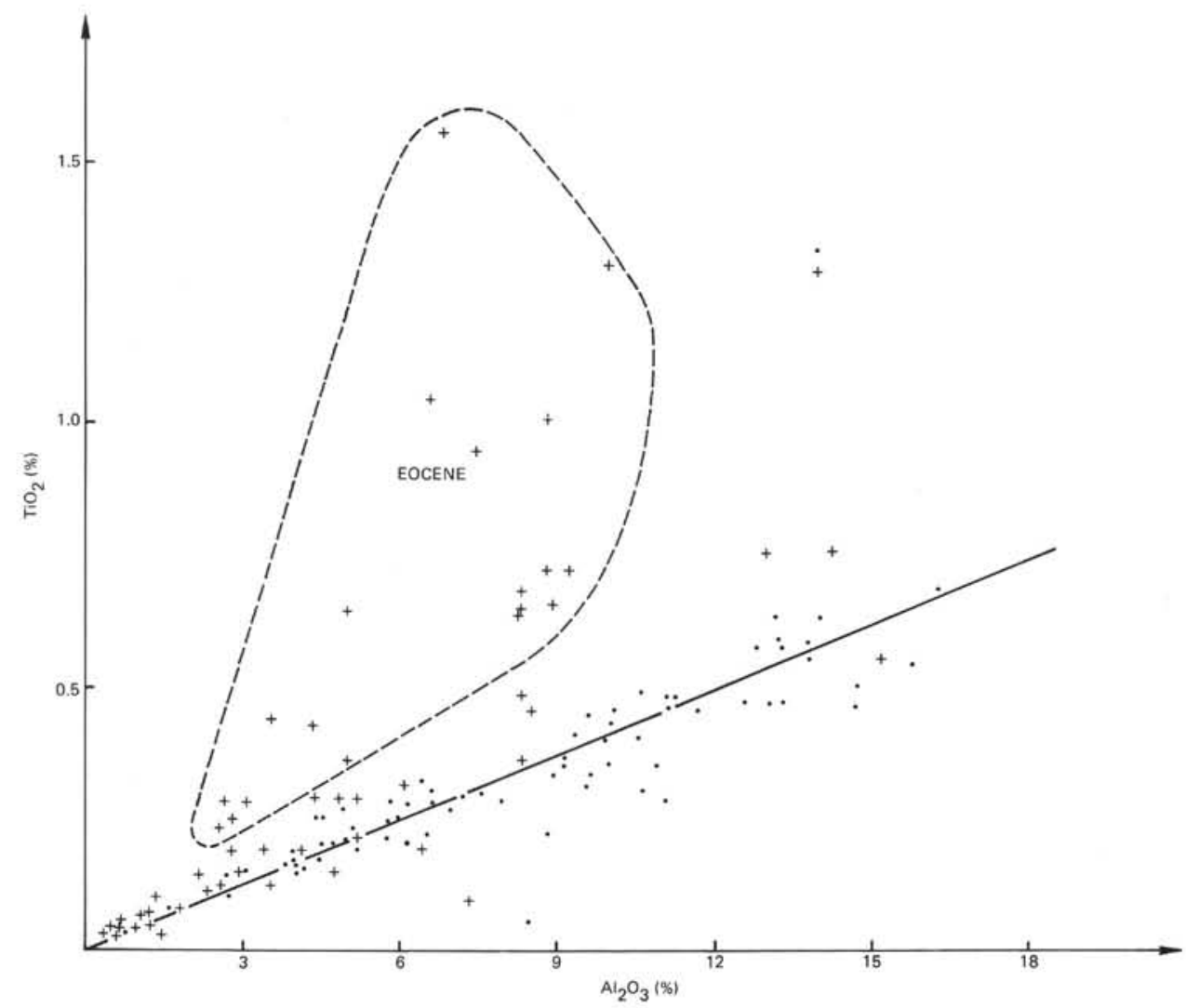

Figure 10. Rockall Plateau and Biscay Bay: $\mathrm{TiO}_{2}=f\left(\mathrm{Al}_{2} \mathrm{O}_{3}\right)$. 


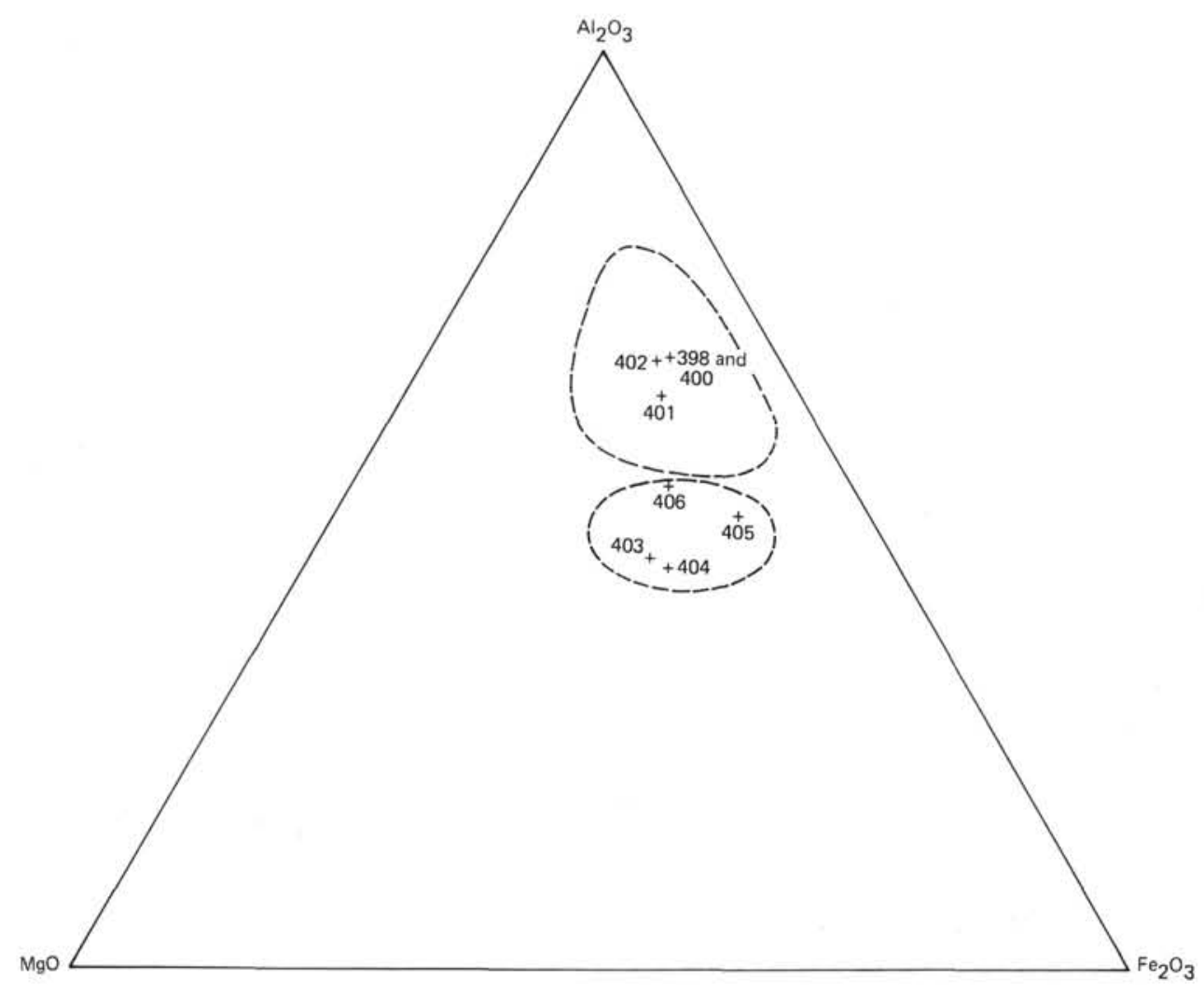

Figure 11. Geochemical average data of each Leg 48 site.

emerged volcanic areas located between Greenland and Europe, which followed the major phase of the opening of Northeast Atlantic (Laughton, Berggren et al., 1972). In the Pleistocene the spread of glaciers provoked an increase in terrigenous supplies which diluted the planktonic carbonates.

\section{GEOGRAPHICAL COMPARISONS-CONCLUSIONS}

Comparison Between North and South Biscay Bay (Leg 48, Sites 399, 400, 401, 402; Leg 47B, Site 398, Chamley et al., 1978)

\section{Common Characteristics}

1) Late Cretaceous to Paleogene sediments in both areas contain abundant crystallized aluminoferrous smectite with isochronous quantitative variations. The smectite was probably derived from a deeply weathered continental source subject to a warm and arid climate with alternating wet and dry seasons.

2) Two intervals of fibrous clay with associated Mn deposition occur in both areas in Albian time (attapulgite = palygorskite) and at the Paleogene/Eocene boundary (attapulgite, sepiolite). Derivation was probably from a chemically basic setting (Millot et al., 1957; Millot, 1964) established on the continental margin under hydrolysing climates. Simultaneous development of fibrous clays is known from the South Atlantic (Chamley, unpublished data, DSDP Leg 40). Fibrous clays in all these DSDP sites are detrital and reworked due to the marginal unstability.
3) Abrupt mineralogical change occurs in the Campanian/Maestrichtian period, manifested by a sudden increase in the quantity of primary minerals. The cause could be a major stage in the North Atlantic widening (Laughton, Berggren et al., 1972; Berggren and Hollister, 1974), favoring the mineralogical supply from high latitudes. Additional causes could be a pre-alpine rejuvenation and/or a continental cooling.

4) Irregular increase in primary minerals and irregular mixed-layers from Oligocene upwards, in relation with a world cooling the major stages of which occur in the upper Miocene and in the Pleistocene (see also Pastouret et al., 1978; Chamley and Giroud d'Argoud, in press). At the same time the marine circulation increased, leading to the development of calcareous plankton and carbonated sediments. In the Pleistocene the Glacial/Interglacial alternation determined an increase in erosion of northern continental rocks, rich in silicated components.

5) The chemical composition of the sediments at Sites 398 and 400 are comparable (Figure 12). This is particularly well demonstrated in the mean compositions (Figure 11) and indicates a common origin for the detrital minerals. The chemical successions with time also follow one another in the same manner at the two sites.

6) Study of geochemical relations confirm the analogies between Sites 400 and 398. In both cases the siliceous phase, well defined by close linkages between $\mathrm{SiO}_{2}, \mathrm{Al}_{2} \mathrm{O}_{3}$, $\mathrm{Fe}_{2} \mathrm{O}_{3}, \mathrm{MgO}$, and $\mathrm{K}_{2} \mathrm{O}$, is marked by the same group of traces $(\mathrm{Ti}, \mathrm{V}, \mathrm{Cr}, \mathrm{Li})$. This fact defines not only identical detrital contributions but also identical sources for these contributions. Moreover in these two sites there exists an 


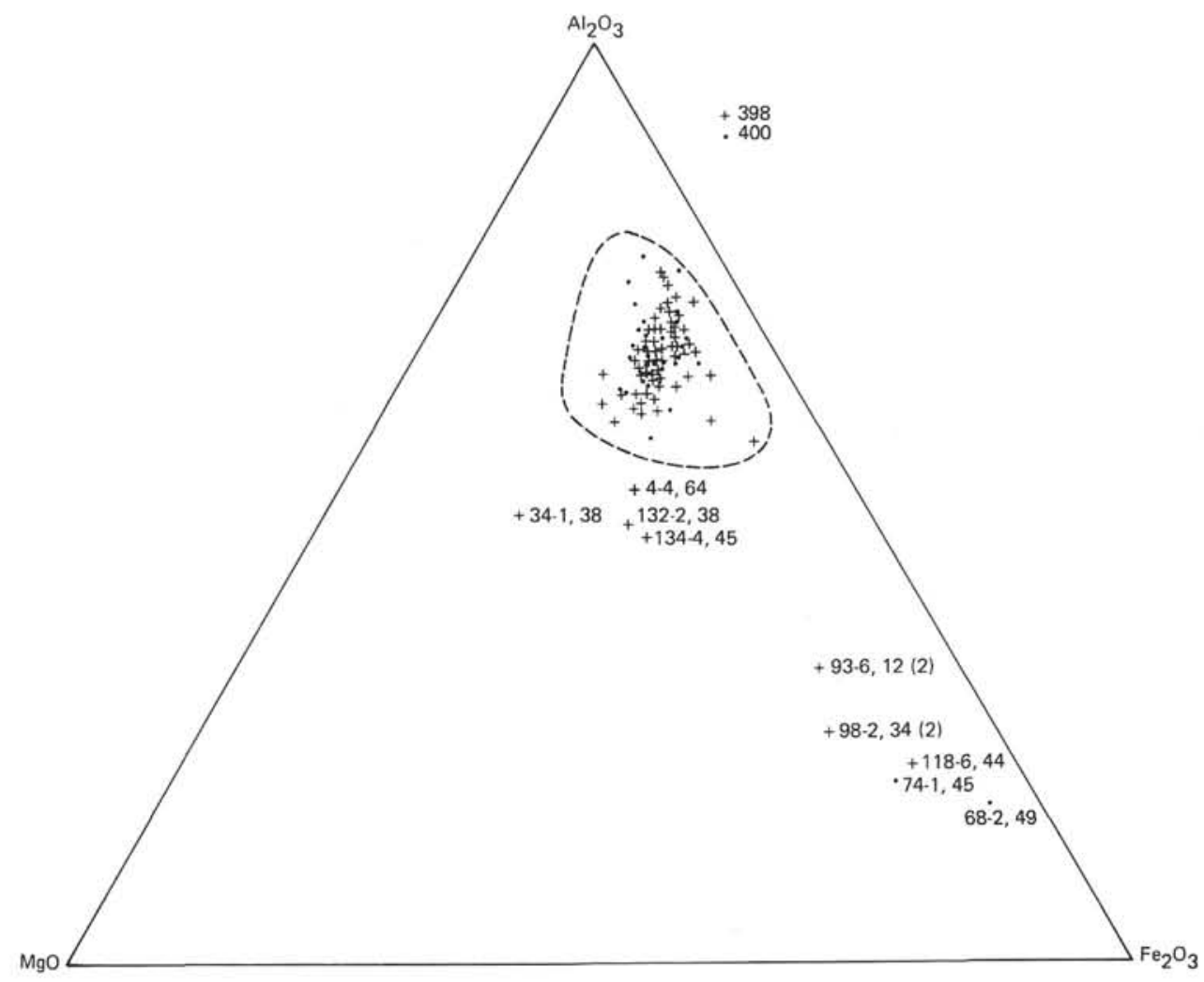

Figure 12. Triangular diagram, $\mathrm{Al}_{2} \mathrm{O}_{3}-\mathrm{Fe}_{2} \mathrm{O}_{3}-\mathrm{MgO}$. Comparison between south and north of Biscay Bay (Sites 399 and 400 and Site 398).

independent metalliferous phase, characterized by transition elements ( $\mathrm{Mn}, \mathrm{Ni}, \mathrm{Co})$. This third phase begins and disappears at the same time as the fibrous clays, that is, it persists from Albian to Oligo-Miocene.

\section{Unique Characteristics}

1) The sediments of the north Biscay Bay sites contain less kaolinite and fibrous clays than those in the south. This evokes the climatic zonation of sedimentary rocks and soils on land masses, favoring kaolinite and fibrous clays in lower latitudes. The occurrence of terrestrial paleoclimatic belts seems to be reflected in sediments as today (Griffin et al., 1968; Pédro, 1968), with major influence of supplies from adjacent continents.

2) Smectite and $\mathrm{MgO}$ increase northward, probably in relation with soil and sediment supplies from the Paris Basin rather than with submarine volcanic activity.

3) More primary minerals (and, consequently, associated chemical elements) occur in the Neogene and Pleistocene sediments in the north than in the south. Probably this points to a manifestation of lower temperatures in the source area that supplied the northern sites, as is the case today (Griffin et al., 1968).

4) In the Albo-Aptian "black shales" in the north diagenesis of organic matter is less marked and concerns mobile chemical elements only ( $\mathrm{Mn}, \mathrm{Fe}, \mathrm{Ca})$, showing the variability of mineral and organic components in this lithological facies (Ryan and Cita, 1977a,b; Deroo et al., 1978; Deroo and Herbin, in press; Tissot et al., this volume).

\section{Comparison Between North Biscay Bay and Rockall Plateau (Sites 399 and 400 to 402 and Sites 403 to 406 )}

\section{Common Characteristics}

The main similarity between the two areas drilled during Leg 48 , and which is equally common to the area located off the Iberian peninsula, invokes the unsteady increase of primary minerals and the occurrence of mixed-layers from late Paleogene onwards and particularly during Neogene and Pleistocene time. That change is illustrated in particular by the decrease of the smectite-Mg couple and the increase of the illite- $\mathrm{SiO}_{2}$ couple. It is a product of general cooling in Middle and Upper Cenozoic, influencing the conditions of erosion, continental pedogenesis, and oceanic circulation.

\section{Unique Characteristics}

1) The geochemistry of the sediments of Paleocene, Eocene, and Oligocene age in the Rockall area are distinctly ferromagnesian and titaniferous (Figures 10, 11, and 13). Figure 11 demonstrates that, for the Rockall sites, the cloud of points is close to the $\mathrm{MgO}$ and $\mathrm{Fe}_{2} \mathrm{O}_{3}$ poles and the dispersion is greater than for the Biscay Bay sites.

2) The analysis shows, for Biscay Bay, there is a close relation in the $\mathrm{Al}_{2} \mathrm{O}_{3} / \mathrm{TiO}_{2}$ bond (due to $\mathrm{Ti}$ in the smectites); the relationship is linear (Figure 10). For the Rockall area a similar relationship occurs, but differs in that 80 per cent of the points fall above the line. This is particularly true for the Eocene section of the Rockall sites. The $\mathrm{Ti}$ is concentrated 


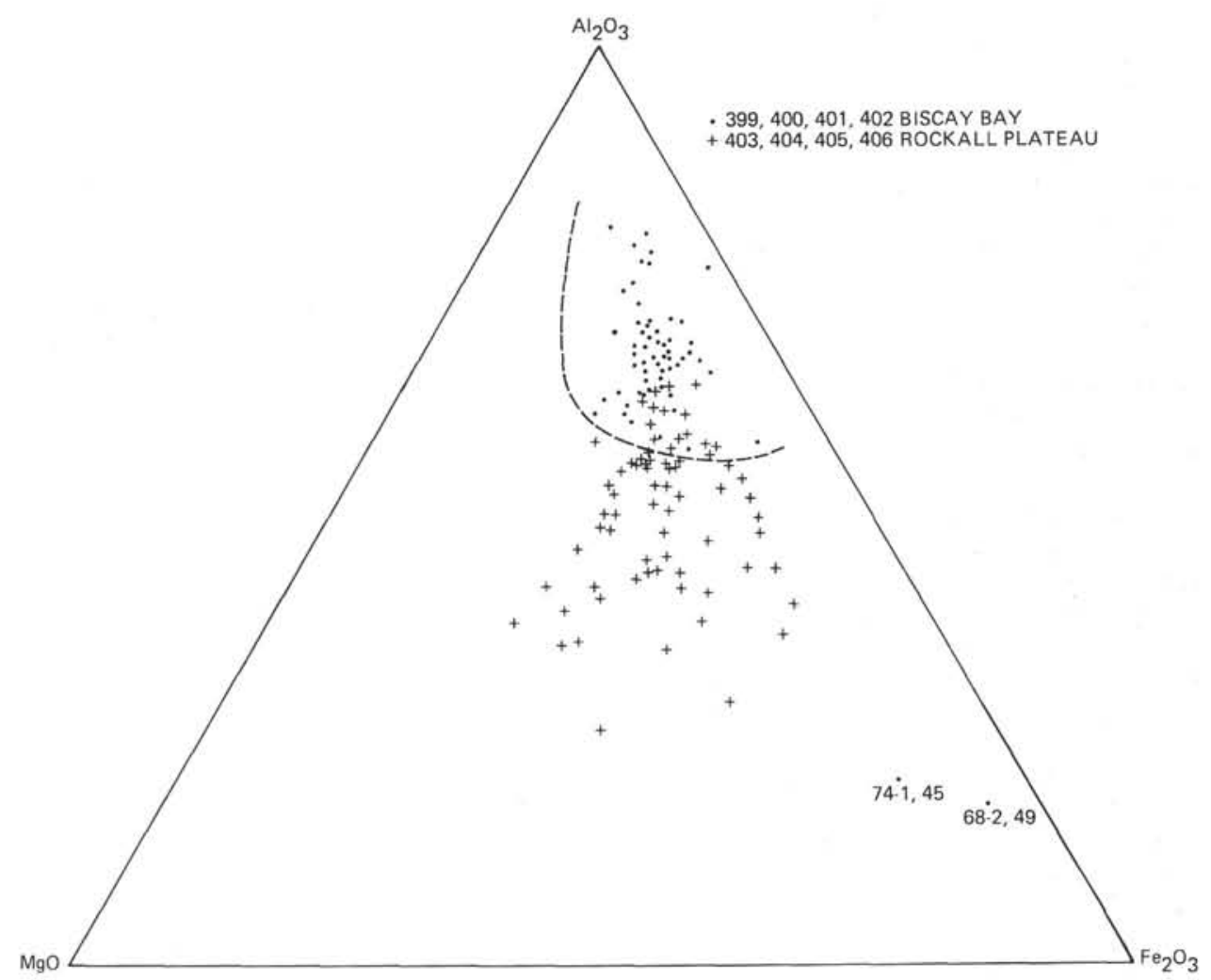

Figure 13. Triangular diagram, $\mathrm{Al}_{2} \mathrm{O}_{3}-\mathrm{Fe}_{2} \mathrm{O}_{3}-\mathrm{MgO}$. Comparison between Biscay Bay and Rockall Plateau.

in the Fe- and Mg-rich smectites (Caillère and Henin, 1963; Deer et al., 1962), and suggests, together with rare earth and $\mathrm{V}, \mathrm{Cr}$, Co data, that the smectite chiefly originated from basic volcanic material.

3) In the Rockall sites, $\mathrm{Mn}$ is not present consistently as a metalliferous phase. We find it in the Eocene as rhodochrosite, associated with other minerals (siderite, glauconite, phosphate; see also Odin, this volume). This suggests an environment reduced by an anaerobic decay of organic material of animal origin (Rivière, 1941). In the sites of the Bay of Biscay, rhodochrosite does not appear after the Albian and especially is not associated with phosphorous. Effectively the reduced conditions are induced by decay of vegetable organic material of detrital origin, suggesting a very different environment.

4) A lesser clay fraction and more abundant carbonate, siliceous and volcaniclastic material occurs in the north, indicating a more oceanic and volcanic environment. This trend increases from Sites 403 and 404 toward Sites 405 and 406.

5) Kaolinite and fibrous clays are less abundant in the clay fraction northward, due to remoteness from continental sources and from less hydrolyzing climatic zones (lower latitudes).

6) The cooling expressed in clay assemblage occurs later and stronger in Rockall area (increase in illite, chlorite, mixed-layers content). The principal causes are the additional influence of volcanic activity to the climatic changes in the setting up of the mineralogical composition, and the vicinity to the cooling sources during the Pleistocene (see Moyes et al., 1974; Chamley, 1975).

\section{ACKNOWLEDGMENTS}

We are grateful to the National Science Foundation (USA) and to the shipboard team of Leg 48 for allowing our shore-based investigations. Geochemical and mineralogical studies received the financial support of C. N. E. X. O. (France) through grants $76 / 5319$ and $76 / 5320$. The mineralogical study profited by the technical assistance of G. Giroud d'Argoud. Scientific comments and assistance were given especially by L. Montadert, G. A. Auffret, and P. C. de Graciansky. We gratefully acknowledge G. A. Auffret and J. Usher for reviewing the manuscript.

\section{REFERENCES}

Caillère, S. and Hénin, S., 1963. Minéralogie des Argiles: Paris, (Masson Edit.).

Chamley, H., 1971. Recherches sur la sédimentation argileuse en Méditerranée: Sci. géol., Mém., Strasbourg, no. 35. , 1975. Remarques sur la sédimentation argileuse en mer de Norvège: Union Océanogr. France, Bull. v. 7, p. 15-20.

Chamley, H. and Giroud d'Argoud, G., in press. Clay mineralogy of Site 397, south of the Canary islands (DSDP Leg 47A). In Ryan, W.B.F., von Rad, U., et al., Initial Reports of the Deep Sea Drilling Project, v. 47, Part 1: Washington (U.S. Government Printing Office).

Chamley, H., Debrabant, P., Foulon, J., Giroud d'Argoud, G., Latouche, C., Maillet, N., Maillot, H., and Sommer, F., in press. Mineralogy and geochemistry of Cretaceous and Cenozoic Atlantic sediments off the Iberian peninsula (Site 
398, Leg 47B DSDP). In Ryan, W.B.F., Sibuet, J.-C., et al., Initial Reports of the Deep Sea Drilling Project, v. 47, Part 2: Washington (U.S. Government Printing Office).

Deer, W.A., Howie, R.A., Zunmann, J., 1962. Sheet silicates in rock-forming minerals: London (Longmans Ed.).

Deroo, G. and Herbin, J.-P., 1978. Organic Geochemistry of Cretaceous cores of well 398D. In Ryan, W.B.F., Sibuet, J.-C., et al., Initial Reports of the Deep Sea Drilling Project, v. 47, Part 2: Washington (U.S. Government Printing Office).

Deroo, G., Herbin, J.P., Rouchaché, J.R., Tissot, B., Albrecht, P., and Dastillung, M., 1978. Organic geochemistry of some Cretaceous claystones from Site 391, Leg 44, western North Atlantic. In Benson, W.E., Sheridan, R.E., Initial Reports of the Deep Sea Drilling Project, v. 44: Washington (U.S. Government Printing Office), p. 593-598.

Estéoule-Choux, J., 1967. Contribution à l'étude des argiles du Massif Armoricain. Argiles des altérations et argiles des bassins sédimentaires tertiaires: Thèse, Sci. nat., Rennes.

Gibbs, R.J., 1977. Clay mineral segregation in the marine environment, J. Sediment. Petrol., v. 47, p. 237-243.

Griffin, J.J., Windom, H., and Goldberg, E.D., 1968. The distribution of clay minerals in the world ocean, Deep-Sea Res., v. 15 , p. $433-459$.

Krauskopf, K.B., 1967. Introduction to geochemistry: New York, (McGraw Hill Comp.).

Laughton, A.S., Berggren, W.A., et al., 1972. Initial Reports of the Deep Sea Drilling Project, v. 12: Washington (U.S. Government Printing Office).

Millot, G., 1964. Géologie des Argiles: Paris (Masson Ed.).

Millot, G., Radier, H., and Bonifas, M., 1957. La sédimentation argileuse à attapulgite et montmorillonite, Soc. géol. France Bull., sér. 6, v. 7, p. 425-434.

Mitsui, K. and Taguchi, K., 1977. Silica mineral diagenesis in Neogene Tertiary shales in the Tempoka district, Hokkaido, Japan, J. Sediment. Petrol., v. 47, p. 158-167.

Moyes, J., Duplessy, J.-C., Gonthier, E., Latouche, C., Maillet, N., Parra, M. and Pujol, C., 1974. Les sédiments profonds actuels et pléistocène récent de l'Atlantique nord-oriental et du Sud de la mer de Norvège, Coll. internat. Exploit. Océans, Bordeaux 1974, v. 4

Paquet, H., 1969. Evolution géochimique des minéraux argileux dans les altérations et les sols des climats méditerranéens et tropicaux à saisons contrastées, Mém. Serv. Carte géol. Alsace-Lorraine, Strasbourg, no. 30.

Pastouret, L., Auffret, G.-A., and Chamley, H., 1978. Microfacies of some sediments from the North Western Atlantic: Paleoceanographic implications (Leg 44 DSDP). In Benson, W.E., Sheridan, R.E., et al., Initial Reports of the Deep Sea Drilling Project, v. 44: Washington (U.S. Government Printing Office).

Pédro, G., 1968. Distribution des principaux types d'altération chimique à la surface du globe. Présentation d'une esquisse géographique, Rev. Géogr. Phys. Géol. dyn., Paris, v. 10, p. 457-470.

Ryan, W.B.F. and Cita, M.B., 1977. Ignorance concerning episodes of ocean-wide stagnation, Mar. Geol., v. 23, p. 197 215.

Rankama, K. and Sahama, T.G., 1950. Geochemistry: Chicago (The Univ. of Chicago Press).

Rivière, A., 1941. Sur la sédimentation phosphatée en milieu marin, Soc. Géol. France. Bull. no. 12, p. 75-77.

Sigl, W., Chamley, H., Fabricius, F., Giroud d'Argoud, G., and Müller, J., 1978. Sedimentology and environmental conditions of sapropels. In Hsü, K.J., Montadert, L.C., et al., Initial Reports of the Deep Sea Drilling Project, v. 42, Part 1: Washington (U.S. Government Printing Office), p. 445-465.

Sommer, F., 1969. Etude géochimique des sédiments paléogènes du bassin de Paris à l'aide de quatre forages profonds. Evolution des minéraux argileux: Thèse, 3ème cycle, Strasbourg.

, 1972. Néogenèse de clinoptilolite dan l'Eocène et l'Oligocène de Casamance (Sénégal), Sci. Géol. Bull., Strasbourg, v. 25, p. 251-258.

Stonecipher, S.H., 1976. Origin, distribution and diagenesis of phillipsite and clinoptilolite in deep-sea sediments, Chem. Geol., v. 17 , p. $307-318$.

von Rad, U. and Rösch, H., 1972. Mineralogy and origin of clay minerals, silica and authigenic silicates in Leg 14 sediments. In Hayes, D.E., Pimm, A.C., et al., Initial Reports of the Deep Sea Drilling Project, v. 14: Washington (U.S. Government Printing Office), p. 727-751.

Wise, S.W., Jr., and Kelts, K.R., 1972. Inferred diagenetic history of a weakly silicified deep sea chalk, Gulf Coast Assoc. Geol. Soc. Trans., v. 22, p. 177-203. 

PLATE 1

Electromicrographs

Figure 1 Sample 400A-64-2, $56 \mathrm{~cm}(\times 25,000)$. Upper Albian. Attapulgite (=palygorskite) in short and straight fibers. Smectite in fleecy particles. Well-shaped illite.

Figure 2 Sample 400A-64-2, $56 \mathrm{~cm}(\times 39,000)$. Upper Albian. Attapulgite, smectite, hexagonal kaolinite.

Figure 3 Sample 401-19-1, $125 \mathrm{~cm}(\times 6800)$. Lower Campanian. Large-sized and well-shaped illite and chlorite, with fleecy smectite.

Figure 4 Sample 401-17-1, $50 \mathrm{~cm}(\times 20,000)$. Early Paleocene. Local increase of straight or flexuous fibrous clays (sepiolite, attapulgite) in a smectite-rich assemblage.

Figure $5 \quad$ Sample $400 \mathrm{~A}-43-3,148 \mathrm{~cm}(\times 39,000)$. Upper Miocene. Smectite, illite, kaolinite, fairly rare attapulgite, fragments of dissolved diatoms.

Figure 6 Sample 400A-20-5, $38 \mathrm{~cm}(\times 39,000)$. Upper Miocene. Smectite, illite, kaolinite, rare attapulgite. 
PLATE 1
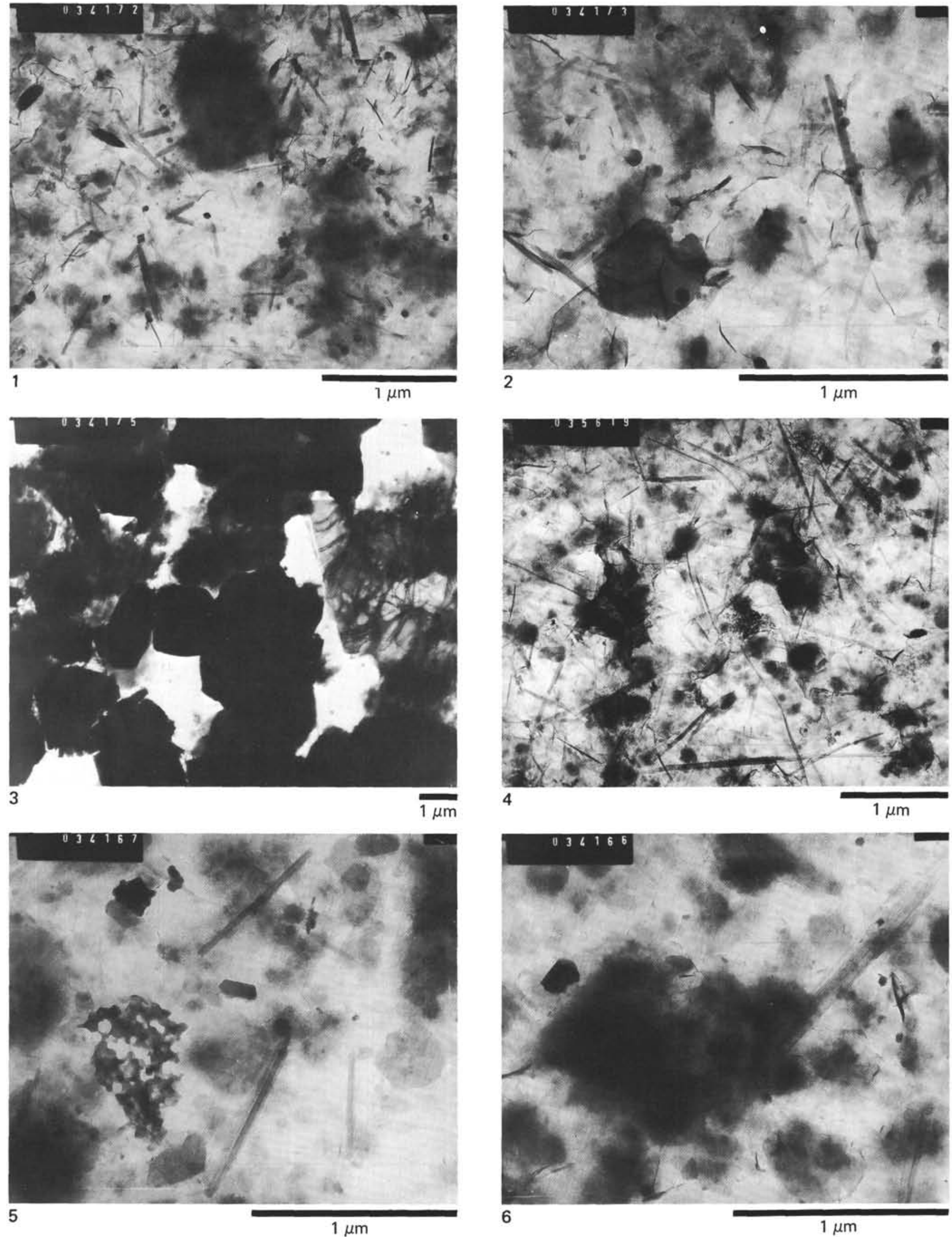